\title{
TNF- $\alpha$ Downregulates Inhibitory Neurotransmission through Protein Phosphatase 1-Dependent Trafficking of $\mathrm{GABA}_{\mathrm{A}}$ Receptors
}

\author{
Horia Pribiag and David Stellwagen \\ Centre for Research in Neuroscience, Department of Neurology and Neurosurgery, Research Institute of the McGill University Health Centre, Montréal, \\ Québec, Canada H3G 1A4
}

Inflammation has been implicated in the progression of neurological disease, yet precisely how inflammation affects neuronal function remains unclear. Tumor necrosis factor- $\alpha(\mathrm{TNF} \alpha)$ is a proinflammatory cytokine that regulates synapse function by controlling neurotransmitter receptor trafficking and homeostatic synaptic plasticity. Here we characterize the mechanisms through which TNF $\alpha$ regulates inhibitory synapse function in mature rat and mouse hippocampal neurons. Acute application of TNF $\alpha$ induces a rapid and persistent decrease of inhibitory synaptic strength and downregulation of cell-surface levels of $\mathrm{GABA}_{\mathrm{A}} \mathrm{Rs}$ containing $\alpha 1, \alpha 2, \beta 2 / 3$, and $\gamma 2$ subunits. We show that trafficking of $\mathrm{GABA}_{\mathrm{A}} \mathrm{Rs}$ in response to TNF $\alpha$ is mediated by neuronally expressed TNF receptor 1 and requires activation of $\mathrm{p} 38 \mathrm{MAPK}$, phosphatidylinositol 3-kinase, protein phosphatase 1 (PP1), and dynamin GTPase. Furthermore, TNF $\alpha$ enhances the association of PP1 with $\mathrm{GABA}_{\mathrm{A}} \mathrm{R} \beta 3$ subunits and dephosphorylates a site on $\beta 3$ known to regulate phospho-dependent interactions with the endocytic machinery. Conversely, we find that calcineurin and PP2A are not essential components of the signaling pathway and that clustering of the scaffolding protein gephyrin is only reduced after the initial receptor endocytosis. Together, these findings demonstrate a distinct mechanism of regulated $\mathrm{GABA}_{\mathrm{A}} \mathrm{R}$ endocytosis that may contribute to the disruption of circuit homeostasis under neuroinflammatory conditions.

\section{Introduction}

Immune molecules expressed in the CNS, such as cytokines, class I major histocompatibility complex, and complement cascade components, are active in a variety of contexts ranging from synapse development to cell survival and synaptic plasticity (Yirmiya and Goshen, 2011). In particular, the proinflammatory cytokine tumor necrosis factor- $\alpha(\mathrm{TNF} \alpha)$ is an important regulator of synapse function implicated in neurotransmitter receptor trafficking (Beattie et al., 2002; Ogoshi et al., 2005; Stellwagen et al., 2005), homeostatic synaptic plasticity (Stellwagen and Malenka, 2006; Kaneko et al., 2008; Steinmetz and Turrigiano, 2010), and regulation of gliotransmission (Santello et al., 2011). TNF $\alpha$ is a proteolytically cleaved transmembrane protein that signals through TNF receptor 1 (TNFR1) and TNFR2 (MacEwan, 2002).

Received Feb. 4, 2013; revised July 29, 2013; accepted Aug. 27, 2013.

Author contributions: H.P. and D.S. designed research; H.P. performed research;H.P. and D.S. analyzed data; H.P. and D.S. wrote the paper.

This work was supported by the Canadian Institutes of Health Research, the Natural Sciences and Engineering Research Council of Canada, the National Alliance for Research on Schizophrenia and Depression Young Investigator Award (D.S.), an Alexander Graham Bell Canada Graduate Doctoral Scholarship (H.P.), and a Doctoral Training Award from the Fonds de la recherche en santé du Québec (H.P.). We thank members of the Stellwagen laboratory and Drs. Keith Murai and Edward Ruthazer for helpful discussions and Meggie Stainforth-Dubois and Erin Downing for technical assistance.

The authors declare no competing financial interests.

Correspondence should be addressed to Dr. David Stellwagen, Centre for Research in Neuroscience, Research Institute of the McGill University Health Centre, Montreal General Hospital, Room L7-217, 1650 Cedar Avenue, Montréal, Québec, Canada H3G 1A4. E-mail: david.stellwagen@mcgill.ca.

DOI:10.1523/JNEUROSCI.0530-13.2013

Copyright $\odot 2013$ the authors $\quad 0270-6474 / 13 / 3315879-15 \$ 15.00 / 0$
Expression of TNF $\alpha$ in the CNS is upregulated by glia in response to inflammatory neurological insults, such as stroke, infection, and neurodegenerative diseases (Tonelli and Postolache, 2005; Frankola et al., 2011), and in response to prolonged neuronal activity blockade (Stellwagen and Malenka, 2006). Neurons respond to elevated levels of TNF $\alpha$ by rapidly increasing excitatory synaptic strength (Tancredi et al., 1992; Beattie et al., 2002; Stellwagen et al., 2005) and weakening inhibitory synaptic strength, resulting in a higher excitatory/inhibitory ratio (Stellwagen et al., 2005). Although the increase in excitatory synaptic strength is known to occur through TNFR1, phosphatidylinositol 3-kinase (PI3K) activity and cell-surface delivery of $\mathrm{Ca}^{2+}$-permeable AMPA receptors (AMPARs; Ogoshi et al., 2005; Stellwagen et al., 2005; Yin et al., 2012), the detailed molecular mechanisms underlying the weakening of inhibitory synaptic strength induced by $\mathrm{TNF} \alpha$ remain essentially unknown.

$\mathrm{GABA}_{\mathrm{A}}$ receptors $\left(\mathrm{GABA}_{\mathrm{A}} \mathrm{Rs}\right)$ are the primary mediators of fast inhibitory neurotransmission in the brain, exerting tight control over the excitatory/inhibitory balance (Mann and Paulsen, 2007; Jacob et al., 2008). Accordingly, selective disruption of $\mathrm{GABA}_{\mathrm{A}} \mathrm{R}$ function leads to homeostatic modifications in circuit development (Duveau et al., 2011; Pallotto et al., 2012), epilepsy (DeLorey et al., 1998), and anxiety-like behavior (Crestani et al., 1999). A pivotal point in the regulation of GABAergic synaptic strength is the dynamic trafficking of $G_{A B A}$ Rs (Luscher et al., 2011). In particular, endocytosis of $\mathrm{GABA}_{\mathrm{A}} \mathrm{Rs}$ is regulated by phosphorylation-dependent binding of the clathrin adaptor protein 2 (AP2) adaptor complex to motifs in the intra- 
cellular domains of $\mathrm{GABA}_{\mathrm{A}} \mathrm{R} \beta$ and $\gamma$ subunits (ArancibiaCárcamo and Kittler, 2009). Phosphoresidues within these motifs are subject to regulation by kinases (e.g., PKA and PKC) and phosphatases (e.g., protein phosphatase 1 [PP1]/ PP2A and calcineurin; Luscher et al., 2011). The effect of TNF $\alpha$ on phospho-dependent regulation of $\mathrm{GABA}_{\mathrm{A}} \mathrm{R}$ trafficking remains unexplored.

Here, using multiple experimental approaches, we characterize the mechanisms through which TNF $\alpha$ downregulates GABAergic neurotransmission in hippocampal neurons. TNF $\alpha$ signals through neuronal TNFR1, p38 MAPK, PI3K, and PP1 to rapidly reduce inhibitory synaptic strength and surface levels of synaptic $\mathrm{GABA}_{\mathrm{A}} \mathrm{Rs}$. These effects persist over time and are followed by a reduction in clustering of the postsynaptic scaffolding protein gephyrin. Moreover, we show that TNF $\alpha$ increases the association of PP1 with $\mathrm{GABA}_{\mathrm{A}} \mathrm{R} \beta 3$, dephosphorylates $\beta 3 \mathrm{~S} 408$ / 409 , and reduces inhibitory synaptic strength via dynamin GTPase activity. Together, these results describe a mechanism of regulated $\mathrm{GABA}_{\mathrm{A}} \mathrm{R}$ endocytosis via which GABAergic inhibition is downregulated under conditions associated with elevated $\mathrm{TNF} \alpha$ levels.

\section{Materials and Methods}

Hippocampal neuron culture. Animal procedures were performed in accordance with the guidelines of the Canadian Council for Animal Care and the Montreal General Hospital Facility Animal Care Committee. All cell culture experiments (except those in Fig. $4 C, D$ ) made use of mixed neuron-glia cultures prepared based on established protocols (Kaech and Banker, 2006) from E17-E18 Sprague Dawley rat hippocampus (of either sex). Briefly, dissociated cells were plated at a density of $2.7 \times$ $10^{4} / \mathrm{cm}^{2}$ on either $12 \mathrm{~mm}$ poly-D-lysine-coated coverslips (Thermo Fisher Scientific) for immunostaining and electrophysiology experiments or on $10 \mathrm{~cm}$ poly-D-lysine-coated tissue culture plates for immunoprecipitation and Western blotting experiments. Culture media consisted of Neurobasal medium supplemented with B-27 and Glutamax (Life Technologies). Glial proliferation was inhibited at $12 \mathrm{~d}$ in vitro with $8 \mu \mathrm{M}$ AraC. Experiments were performed at $14-22 \mathrm{~d}$ in vitro. For experiments in Figure 4, $C$ and $D$, glia derived from P1-P2 mouse forebrain (of either sex) were grown to confluence on poly-D-lysine-coated 24-well plates. Neurons were dissociated from P0 mouse hippocampus [of either sex, C57BL/6J wild type (WT; The Jackson Laboratory) or TNFR1 ${ }^{-1-}$ (kindly provided by Dr. P. Brodt, McGill University, Montréal, Québec, Canada) ], seeded at a density of $3.7 \times 10^{4} / \mathrm{cm}^{2}$ on $12 \mathrm{~mm}$ poly-D-lysinecoated coverslips for $2 \mathrm{~h}$, transferred to the glial culture plate wells, and grown in the same media used for rat cultures; additional glial proliferation was inhibited with AraC.

Culture electrophysiology and treatments. Miniature IPSCs (mIPSCs) were recorded at room temperature using the whole-cell patch-clamp method from neurons superfused with ACSF containing the following (in mM): $115 \mathrm{NaCl}, 5 \mathrm{KCl}, 23$ glucose, 26 sucrose, $4.2 \mathrm{HEPES}, 2.5 \mathrm{CaCl}_{2}$, and $1.3 \mathrm{MgCl}_{2}$, pH 7.2 (osmolality, 295-305 mOsm). Recording pipettes were pulled from borosilicate glass (King Precision Glass) to an open-tip resistance of 3-6 $\mathrm{M} \Omega$ and filled with an internal solution of the following (in mM): $127 \mathrm{CsCl}, 8 \mathrm{NaCl}, 1 \mathrm{CaCl}_{2}, 10 \mathrm{HEPES}, 10 \mathrm{EGTA}, 0.3 \mathrm{Na}_{3}$-GTP, and $2 \mathrm{Mg}$-ATP, pH 7.2 (osmolality, 280-290 mOsm). To isolate mIPSCs, 200 nм TTX, $10 \mu \mathrm{m}$ NBQX, and $25 \mu \mathrm{m}$ D-APV (Tocris Bioscience) were added to the external solution, and recordings were obtained at $V_{\mathrm{h}}=$ $-70 \mathrm{mV}$. Signals were amplified and filtered $(1 \mathrm{kHz})$ using an Axopatch 200B amplifier, sampled at $5 \mathrm{kHz}$ using a Digidata 1440A, and recorded with Clampex 10.3 (Molecular Devices). Analyses of mIPSC amplitude, frequency, $10-90 \%$ rise time, and decay tau were performed using Clampfit 10.3 (Molecular Devices). Only cells with a stable series resistance of $<25 \mathrm{M} \Omega$ throughout the recording period were included in the analysis. Treatments were performed by adding recombinant mouse TNF $\alpha$ [at the indicated concentrations in Fig. 1 and at $100 \mathrm{ng} / \mathrm{ml}$ (6 nM) for all other figures; Kamiya Biomedical] to a defined volume of conditioned growth media originating from the wells being treated and return- ing the plate to the incubator $\left(37^{\circ} \mathrm{C}, 5 \% \mathrm{CO}_{2}\right)$ for $45 \mathrm{~min}$. Coverslips were then transferred to the recording chamber, and recordings were obtained within $75 \mathrm{~min}$. For treatments with pharmacological inhibitors (Tocris Bioscience) of dynamin GTPase (dynasore, $80 \mu \mathrm{M}$ ), PP1/PP2A (okadaic acid, $0.5 \mu \mathrm{M}$ ), PP1 (tautomycetin, $10 \mathrm{nM}$ ), and PP2A (fostriecin, $10 \mathrm{nM}$ ), the inhibitor or its corresponding solvent was applied as above but for 55 min (i.e., $10 \mathrm{~min}$ before $\mathrm{TNF} \alpha$ ). For experiments examining multiple treatment conditions, control (Ctrl) and treated cells were recorded on the same day. Data from multiple recording days were then pooled to obtain group data for each experiment.

Immunocytochemistry and treatments. For surface $\mathrm{GABA}_{\mathrm{A}} \mathrm{R}$ immunostaining, cultured cells were live labeled by washing with ice-cold ACSF and incubating with primary antibody in ACSF on ice. The following primary antibodies were used to target the extracellular (N-terminal) domains of $\mathrm{GABA}_{\mathrm{A}} \mathrm{R}$ subunits: anti-GABA $\mathrm{R} \alpha 1$ (1:400; catalog \#AGA001; Alomone Labs), anti-GABA $\mathrm{A}_{\mathrm{A}} \alpha 2$ (1:500; catalog \#224103; Synaptic Systems), anti-GABA $A_{A} \alpha 5$ (1:1000; kind gift from Dr. J.-M. Fritschy, University of Zürich, Zürich, Switzerland), anti-GABA ${ }_{A}$ R $\beta 2 / 3$ (1:100; catalog $\#$ MAB341; Millipore), and anti-GABA ${ }_{A} R \quad \gamma 2$ (1:100; catalog \#AGA-005; Alomone Labs). Cells were then washed three times with ice-cold ACSF and fixed in 2\% paraformaldehyde solution for $15 \mathrm{~min}$. Appropriate fluorescent secondary antibodies (1:1000; Alexa Fluor; Life Technologies) were then applied for $1 \mathrm{~h}$ at room temperature in a PBS solution containing 3\% bovine serum albumin (BSA) and 2\% normal goat serum (NGS). For double immunostaining of gephyrin and microtubule-associated protein 2 (MAP2), or glutamic acid decarboxylase 65 (GAD65) and MAP2, cells were washed with ice-cold ACSF, fixed in $2 \%$ paraformaldehyde for $15 \mathrm{~min}$, permeabilized with $0.1 \%$ Triton X-100 for 3 min, blocked with PBS/3\% BSA/2\% NGS solution for 10 $\mathrm{min}$, and incubated with primary antibodies in $\mathrm{PBS} / 3 \% \mathrm{BSA} / 2 \% \mathrm{NGS}$ for $2 \mathrm{~h}$ at room temperature. The following primary antibodies were used: anti-gephyrin (1:400; catalog \#147011; Synaptic Systems), antiGAD65/67 (1:500; GAD-6; Developmental Studies Hybridoma Bank, University of Iowa, Iowa City, IA), and anti-MAP2 (1:1000; catalog \#188004; Synaptic Systems). For determining the percentage of cells expressing high levels of $\mathrm{GABA}_{\mathrm{A}} \mathrm{R} \alpha 1$ that are GABAergic interneurons, surface $\alpha 1$ subunit was immunolabeled as above; cells were then fixed, permeabilized, and immunostained with anti GAD65/67 (GAD-6) as above. Treatments with TNF $\alpha(100 \mathrm{ng} / \mathrm{ml})$ and pharmacological inhibitors were performed as for electrophysiology experiments. Inhibitors (Tocris Bioscience) were as follows: PKA (KT $5720[(9 S, 10 R, 12 R)$ 2,3,9,10,11,12-hexahydro-10-hydroxy-9-methyl-1-oxo-9,12-epoxy-1 $H$-diindolo[1,2,3-fg:3', 2', $1^{\prime}$-kl] pyrrolo[3,4-i] [1,6] benzodiazocine-10carboxylicacid hexyl ester]; $1 \mu \mathrm{M}$ ), PKC [Gö 6983 (2-[1-(3-dimethylaminopropyl)-5-methoxyindol-3-yl]-3-(1H-indol-3-yl)maleimide); $1 \mu \mathrm{M}]$, PI3K (wortmannin, $100 \mathrm{nM}$ ), p38 MAPK (SB 202190 [4-(4-fluorophenyl)-2-(4hydroxyphenyl)-5-(4-pyridyl) $1 \mathrm{H}$-imidazole]; $10 \mu \mathrm{M}$ ), calcineurin (cyclosporin A, $20 \mu \mathrm{M}$ ), and PP1/PP2A (okadaic acid, 0.05 or $0.5 \mu \mathrm{M}$ ). TNF $\alpha$ receptor function was blocked by starting with a $10 \mathrm{~min}$ pretreatment with either anti-TNFR1 neutralizing antibody $(5 \mu \mathrm{g} / \mathrm{ml}$; catalog \#MAB430; R\&D Systems) or anti-TNFR2 neutralizing antibody $(2 \mu \mathrm{g} / \mathrm{ml}$; catalog \#AF726; R\&D Systems), before adding TNF $\alpha(100 \mathrm{ng} / \mathrm{ml})$ for an additional $45 \mathrm{~min}$.

Image acquisition and analysis. All images were acquired blind to the experimental conditions, using identical acquisition parameters across all coverslips in each experiment. Images of surface $\mathrm{GABA}_{\mathrm{A}} \mathrm{R}$ immunostaining were captured using a CCD camera (Hamamatsu Orca-R2) mounted on an epifluorescence microscope [63×, 1.42 numerical aperture (NA); Olympus BX61]. All other images were acquired as single optical sections using a confocal microscope $(63 \times$, NA 1.42; Olympus FV1000). Each experimental condition was represented by two to three coverslips per experiment, and $\sim 10-20$ images were acquired per coverslip. Image analysis was performed essentially as described previously (Stellwagen et al., 2005). Briefly, unadjusted whole images were analyzed using NIH ImageJ software, applying identical analysis parameters across all conditions within each experiment. For surface $\mathrm{GABA}_{\mathrm{A}} \mathrm{R}$ immunostaining, the area selected by a low threshold was used to approximate somatodendritic area, and a high threshold was used to select receptor puncta. High-threshold selections were analyzed using the "Analyze Particles" function, with particle size restricted to $1 \mu \mathrm{m}^{2}$ to exclude selec- 
A

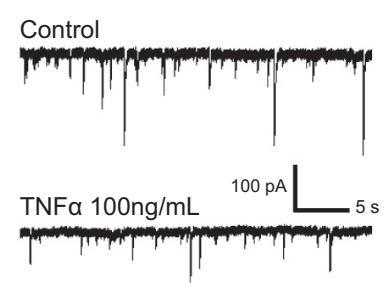

B

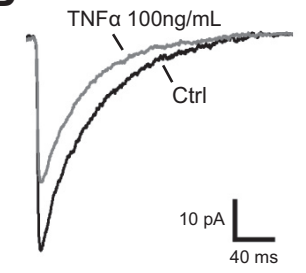

C

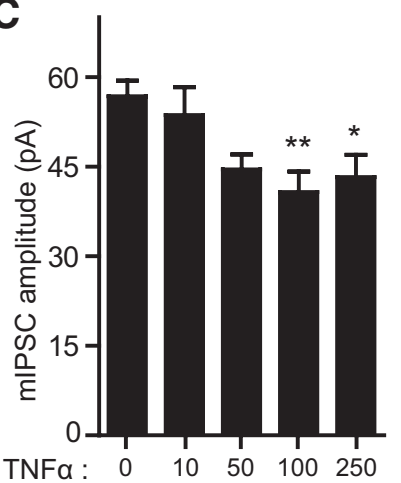

(ng/mL)
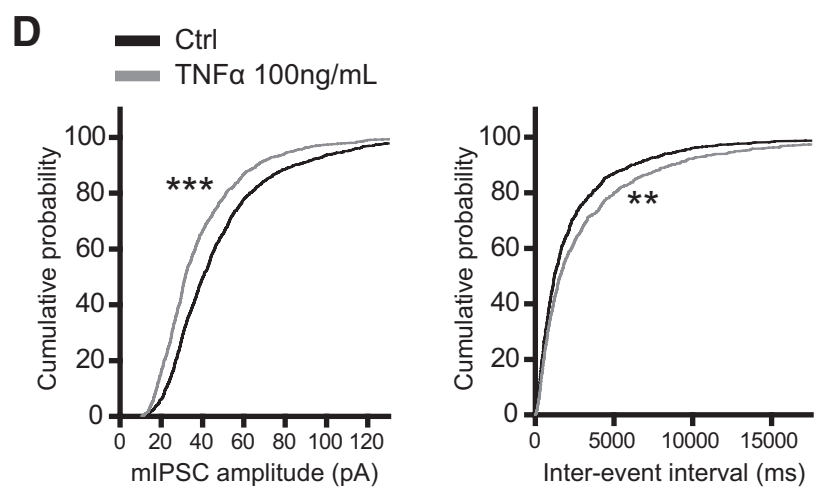

E

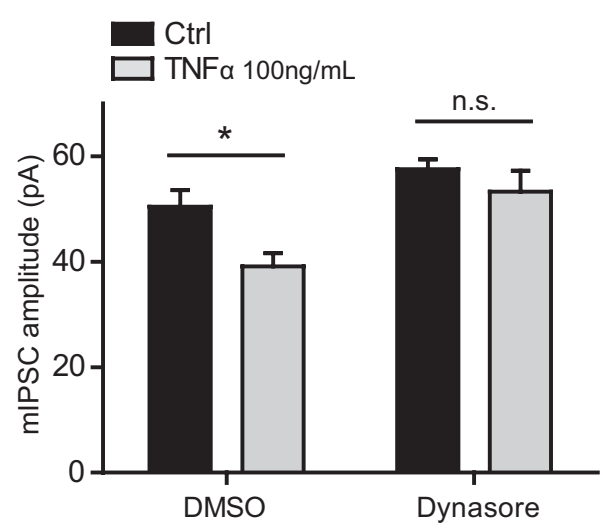

Figure 1. TNF $\alpha$ downregulates inhibitory synaptic strength via dynamin GTPase activity.A, Representative traces of $\mathrm{mIPSC}$ recordings from untreated (Control) and TNF $\alpha$-treated cultured neurons (100 ng/ml, $45 \mathrm{~min}$ ). B, Superimposed average mIPSC traces from an untreated neuron (Ctrl, black trace) and a TNF $\alpha$-treated neuron (gray trace), showing a reduction in mIPSC amplitude in response to TNF $\alpha$ (100 $\mathrm{ng} / \mathrm{ml}, 45 \mathrm{~min})$. C, Group data showing a reduction of average mIPSC amplitude (left) and $\mathrm{mIPSC}$ frequency (right) in response to various concentrations of TNF $\alpha$ applied for $45 \mathrm{~min}$ ( $n=$ $14-23$ cells in each condition; one-way ANOVA, Tukey's post hoc test, ${ }^{*} p<0.05,{ }^{* *} p<0.01$, ${ }^{* * *} p<0.001$ ). D, Cumulative distribution plots of mIPSC amplitudes (left) and interevent intervals (right) from untreated (black traces) and TNF $\alpha$-treated ( $100 \mathrm{ng} / \mathrm{ml}, 45 \mathrm{~min}$; gray traces) neurons ( $\sim 1200$ events from each condition; ${ }^{* *} p<0.005$, ${ }^{* *} p<0.0001$, Kolmogorov-Smirnov test). $\boldsymbol{E}$, Pretreatment with the dynamin GTPase inhibitor dynasore $(80 \mu \mathrm{m})$ blocks the TNF $\alpha$-induced (100 $\mathrm{ng} / \mathrm{ml}, 45 \mathrm{~min}$ ) reduction of mIPSC amplitude ( $n=16-18$ cells in each condition; two-way ANOVA, Bonferroni's post hoc test, ${ }^{*} p<0.05$; n.S., not significant). tions of large bright areas that do not represent receptor puncta. The total particle area of each image was divided by its corresponding lowthreshold area to obtain values normalized to somatodendritic area. The resulting values were then expressed as percentage control to obtain "cluster area" as reported in Results. The same analysis was used for experiments in which cells were permeabilized and double immunostained for gephyrin plus MAP2 or GAD65 plus MAP2, except that (1) particle size was restricted to $2 \mu \mathrm{m}^{2}$ for gephyrin images and $4 \mu \mathrm{m}^{2}$ for GAD65 images and (2) somatodendritic area was determined from corresponding MAP2 images. Cluster density was obtained by normalizing particle count to somatodendritic area for each image and expressing as percentage control. "Average cluster size" is average particle size expressed as percentage control. Because cluster area is a measure of the summated puncta area per image, it represents a combined measure of cluster density and average cluster size.

Culture cell-surface biotinylation, immunoprecipitation, and Western blotting. For surface biotinylation assays, cells were treated with TNF $\alpha$ $(100 \mathrm{ng} / \mathrm{ml})$ for $45 \mathrm{~min}$ in conditioned growth media, washed three times with ice-cold ACSF, and incubated for $30 \mathrm{~min}$ with $0.2 \mathrm{mg} / \mathrm{ml} \mathrm{Sulfo-}$ NHS-SS-Biotin (Thermo Fisher Scientific) diluted in ice-cold ACSF. Cells were then washed three times with ice-cold ACSF containing 100 mM glycine and lysed in $20 \mathrm{~mm}$ HEPES, pH 7.4, $150 \mathrm{~mm} \mathrm{NaCl}, 1 \%$ Triton X-100, 0.1\% SDS, 1 mм EDTA, 1 mм PMSF, 50 mм NaF, 1 mм Na $\mathrm{VO}_{4}$, and protease inhibitor mixture (BioShop Canada). Biotinylated proteins were isolated by incubating lysates with NeutrAvidin agarose resin (Thermo Fisher Scientific) for $1 \mathrm{~h}$ at $4^{\circ} \mathrm{C}$. Biotinylated proteins were eluted with $2 \times$ SDS sample buffer and analyzed by SDS-PAGE along with corresponding total lysates.

For immunoprecipitation experiments cells were treated with TNF $\alpha$ (100 ng/ml) for $30 \mathrm{~min}$, washed two times with ice-cold ACSF, and lysed in $20 \mathrm{~mm}$ HEPES, pH 7.4, $150 \mathrm{~mm} \mathrm{NaCl}, 1 \%$ NP-40, 1 mM EDTA, $1 \mathrm{~mm}$ PMSF, $50 \mathrm{~mm} \mathrm{NaF}, 1 \mathrm{~mm} \mathrm{Na}_{3} \mathrm{VO}_{4}$, and protease inhibitor mixture (BioShop Canada). Lysates were precleared with protein $\mathrm{A} / \mathrm{G}$ agarose beads (Thermo Fisher Scientific) and incubated with $2 \mu \mathrm{g}$ of anti-GABA $\mathrm{R} \beta 3$ (catalog \#75-149; Neuromab) per milligram of lysate protein. Precipitates were eluted with $2 \times$ SDS sample buffer and analyzed by SDS-PAGE together with corresponding unprecipitated lysates.

Gels were transferred onto PVDF membrane and immunoblotted with anti-GABA $A_{A}$ R $\beta 3$ (1:500; catalog \#75-149; Neuromab), anti-GABA $A_{A} R \beta 3$ (1:400; catalog \#NB100-66169; Novus Biologicals), anti-GluA1 (1:1000; catalog \#AB1504; Millipore), anti-phospho-p38 MAPK (1:1000; catalog \#9215; Cell Signaling Technology), anti-total p38 MAPK (1:1000; catalog \#9212; Cell Signaling Technology), anti-phospho Akt (1:2000; catalog \#4060; Cell Signaling Technology), anti-total Akt (1:1000; catalog \#4685; Cell Signaling Technology), anti- $\alpha$-tubulin (1:5000; catalog \#05-289; Millipore), anti$\mathrm{GABA}_{\mathrm{A}} \mathrm{R} \beta 3$ phospho-S408/409 (1:250; catalog \#612-401-D51; Rockland), anti-PP1 $\alpha$ (1:1000; catalog \#1950-1; Epitomics), and anti-PP2A (1:1000; catalog \#1512-1; Epitomics). Quantitative analyses of Western blots were performed by determining band intensities on autoradiography film (Denville Scientific), using NIH ImageJ software. For surface biotinylation assays, "surface" quantifications depict surface/total ratios, and "total" quantifications depict total $/ \alpha$-tubulin ratios. For immunoprecipitation experiments quantifications depict coimmunoprecipitation $\mathrm{PP} 1 / \beta 3$ or $\mathrm{PP} 2 \mathrm{~A} / \beta 3$ ratios.

Acute hippocampal slice cell-surface biotinylation and Western blotting. Coronal slices (300 $\mu \mathrm{m}$ thick) of the dorsal hippocampus were prepared using a vibratome (Leica VT1200S), from 6- to 9-week-old C57BL/6J WT mice (of either sex) and allowed to recover at $\sim 32^{\circ} \mathrm{C}$ for $30 \mathrm{~min}$ in ACSF containing $119 \mathrm{~mm} \mathrm{NaCl}, 26.2 \mathrm{~mm} \mathrm{NaHCO}_{3}, 11 \mathrm{~mm}$ glucose, $2.5 \mathrm{~mm} \mathrm{KCl}$, $1 \mathrm{mM} \mathrm{NaH}_{2} \mathrm{PO}_{4}, 2.5 \mathrm{mM} \mathrm{CaCl}_{2}$, and $1.3 \mathrm{mM} \mathrm{MgCl}_{2}$, saturated with $95 \%$ $\mathrm{O}_{2} / 5 \% \mathrm{CO}_{2}$. Slices were then incubated in the same solution, at room temperature, with TNF $\alpha(100 \mathrm{ng} / \mathrm{ml}, 1 \mathrm{~h})$. Next, slices were incubated for $45 \mathrm{~min}$ in ice-cold ACSF solution containing $1 \mathrm{mg} / \mathrm{ml}$ Sulfo-NHS-SSBiotin (Thermo Fisher Scientific). Slices were then washed three times with ice-cold ACSF containing $100 \mathrm{~mm}$ glycine and lysed in $20 \mathrm{~mm}$ HEPES, pH 7.4, $150 \mathrm{~mm} \mathrm{NaCl}, 1 \%$ Triton X-100, 0.1\% SDS, 1 mm EDTA, $1 \mathrm{~mm}$ PMSF, $50 \mathrm{~mm} \mathrm{NaF}, 1 \mathrm{~mm} \mathrm{Na}_{3} \mathrm{VO}_{4}$, and protease inhibitor mixture (BioShop Canada). Biotinylated proteins were isolated, SDS-PAGE was performed, PVDF membranes were immunoblotted, and quantifications were performed as for culture experiments. 
Acute slice electrophysiology and treatments. Coronal slices of the dorsal hippocampus were prepared and treated with TNF $\alpha$ as for cell-surface biotinylation experiments, from 5- to 8-week-old C57BL/6J WT mice (of either sex). DMSO $(0.1 \%)$ or tautomycetin (10 nM, in DMSO) were added to the treatment chamber $20 \mathrm{~min}$ before adding TNF $\alpha$. Slices were placed in a submersion-type recording chamber and perfused $(\sim 1.5 \mathrm{ml} /$ $\mathrm{min}$ ) at $30^{\circ} \mathrm{C}$ with $\mathrm{ACSF}$ containing $119 \mathrm{~mm} \mathrm{NaCl}, 26.2 \mathrm{~mm} \mathrm{NaHCO}_{3}, 11$ mu glucose, $2.5 \mathrm{~mm} \mathrm{KCl}, 1 \mathrm{~mm} \mathrm{NaH} \mathrm{PO}_{4}, 2.5 \mathrm{~mm} \mathrm{CaCl}_{2}$, and $1.3 \mathrm{~mm}$ $\mathrm{MgCl}_{2}$, saturated with $95 \% \mathrm{O}_{2} / 5 \% \mathrm{CO}_{2}$. Whole-cell patch-clamp recordings were obtained from hippocampal CAl pyramidal neurons under visual guidance by infrared differential interference microscopy (Nikon Eclipse FN1). mIPSCs were pharmacologically isolated, recorded, and analyzed as for culture experiments.

Statistical analyses. Statistical analysis and plotting were performed with Prism 5 (GraphPad Software). All data were obtained from a minimum of three independent experiments and presented as mean \pm SEM.

\section{Results}

TNF $\alpha$ rapidly downregulates inhibitory synaptic strength via dynamin GTPase activity

To study the acute effects of TNF $\alpha$ on inhibitory neurotransmission, we recorded mIPSCs from hippocampal neuron cultures treated with various concentrations of TNF $\alpha$ for 45 min (Fig. $1 A-D$ ). Consistent with previous findings (Stellwagen et al., 2005), TNF $\alpha$ treatment significantly reduced average mIPSC amplitude, exerting a gradual effect that reached a plateau by 100 $\mathrm{ng} / \mathrm{ml}(\mathrm{Ctrl}, 56.8 \pm 2.6 \mathrm{pA} ; \mathrm{TNF} \alpha$ at $10 \mathrm{ng} / \mathrm{ml}, 53.7 \pm 4.6 \mathrm{pA}$; $\mathrm{TNF} \alpha$ at $50 \mathrm{ng} / \mathrm{ml}, 44.52 \pm 2.5 \mathrm{pA} ; \mathrm{TNF} \alpha$ at $100 \mathrm{ng} / \mathrm{ml}, 40.8 \pm 3.4$ $\mathrm{pA} ; \mathrm{TNF} \alpha$ at $250 \mathrm{ng} / \mathrm{ml}, 43.3 \pm 3.7 \mathrm{pA}$; Fig. $1 C$, left). In contrast, mIPSC frequency was significantly reduced starting at $10 \mathrm{ng} / \mathrm{ml}$ (Ctrl, $1.86 \pm 0.22 \mathrm{~Hz}$; TNF $\alpha$ at $10 \mathrm{ng} / \mathrm{ml}, 0.97 \pm 0.17 \mathrm{~Hz} ; \mathrm{TNF} \alpha$ at $50 \mathrm{ng} / \mathrm{ml}, 1.02 \pm 0.15 \mathrm{~Hz}$; TNF $\alpha$ at $100 \mathrm{ng} / \mathrm{ml}, 0.64 \pm 0.10 \mathrm{~Hz}$; $\mathrm{TNF} \alpha$ at $250 \mathrm{ng} / \mathrm{ml}, 0.98 \pm 0.09 \mathrm{~Hz}$; Fig. $1 C$, right), suggesting that, at least in a mixed population of cultured hippocampal neurons, TNF $\alpha$ may act presynaptically to regulate neurotransmitter release probability at inhibitory synapses. For subsequent experiments, we focused on the $100 \mathrm{ng} / \mathrm{ml}$ dose because it exerts the strongest effect on quantal amplitude and it is the most commonly used concentration when studying $\mathrm{TNF} \alpha$-dependent receptor trafficking at hippocampal synapses (Beattie et al., 2002; Ogoshi et al., 2005; Stellwagen et al., 2005; Stellwagen and Malenka, 2006; Leonoudakis et al., 2008). We further determined that mIPSC $10-90 \%$ rise time (Ctrl, $2.06 \pm 0.08 \mathrm{~ms} ; \mathrm{TNF} \alpha$, $2.26 \pm 0.18 \mathrm{~ms}$; Student's $t$ test, $p=0.30$ ) and decay time (Ctrl, $41.6 \pm 0.95 \mathrm{~ms} ; \mathrm{TNF} \alpha, 40.3 \pm 1.10 \mathrm{~ms}$; Student's $t$ test, $p=0.40$ ) were unaffected by TNF $\alpha$ treatment ( $100 \mathrm{ng} / \mathrm{ml}, 45 \mathrm{~min}$ ), implying no substantial change in the subunit composition of synaptic $\mathrm{GABA}_{\mathrm{A}}$ Rs. As an additional control, we recorded cells treated with denatured (boiled) TNF $\alpha$ and observed no significant differences compared with untreated control cells (Ctrl, $55.4 \pm 3.7$ $\mathrm{pA}, 1.56 \pm 0.28 \mathrm{~Hz}, n=11$ cells; boiled TNF $\alpha$ at $250 \mathrm{ng} / \mathrm{ml}$, $53.8 \pm 5.7 \mathrm{pA}, 1.48 \pm 0.27 \mathrm{~Hz}, n=8$ cells; Student's $t$ test, $p=$ 0.81 for amplitude and $p=0.86$ for frequency).

The rapid reduction of mIPSC amplitude in response to $\mathrm{TNF} \alpha$ could be attributed to reduced $\mathrm{GABA}_{\mathrm{A}} \mathrm{R}$ delivery to the synapse, reduced receptor stability at the synapse, or increased receptor endocytosis (Luscher et al., 2011). Because treatment with TNF $\alpha$ is known to cause a nearly twofold increase in the internalization of antibody-labeled $\mathrm{GABA}_{\mathrm{A}} \mathrm{Rs}$ (Stellwagen et al., 2005), we suspected that the majority of the reduction in inhibitory synaptic strength would be endocytosis dependent. Endocytosis of $\mathrm{GABA}_{\mathrm{A}} \mathrm{Rs}$ occurs primarily via an AP2/clathrin/ dynamin-dependent mechanism (Kittler et al., 2000, 2005, 2008; Kanematsu et al., 2007); therefore, in a separate set of experiments, we pretreated cultures with the dynamin GTPase inhibitor dynasore (Macia et al., 2006) and measured mIPSC amplitudes in response to TNF $\alpha$ (Fig. 1E). The TNF $\alpha$-induced reduction of mIPSC amplitude was blocked by dynasore (DMSO pretreatment: Ctrl, $50.4 \pm 3.2 \mathrm{pA}$, $0.84 \pm 0.15 \mathrm{~Hz} ; \mathrm{TNF} \alpha, 39.1 \pm 2.5 \mathrm{pA}, 0.75 \pm 0.10 \mathrm{~Hz}$; dynasore pretreatment: Ctrl, $57.5 \pm 1.9 \mathrm{pA}, 3.51 \pm 0.68 \mathrm{~Hz} ; \mathrm{TNF} \alpha, 53.3 \pm 3.9$ pA, $4.05 \pm 0.73 \mathrm{~Hz}$ ), suggesting that TNF $\alpha$ reduces the strength of hippocampal inhibitory synapses primarily through $G_{A B A} R$ endocytosis.

\section{TNF $\alpha$ rapidly downregulates cell-surface levels of $\mathrm{GABA}_{\mathrm{A}} \mathrm{Rs}$}

$\mathrm{GABA}_{\mathrm{A}} \mathrm{Rs}_{\mathrm{s}}$ consist of heteropentameric assemblies of diverse subunit composition, resulting in receptor subtypes that differ in expression, cell-surface localization, pharmacology, and function (Pirker et al., 2000; Möhler et al., 2004; Farrant and Nusser, 2005; Fritschy et al., 2012). At hippocampal synapses, $\mathrm{GABA}_{\mathrm{A}} \mathrm{Rs}$ are composed of combinations of two $\alpha 1-\alpha 3$ subunits, two $\beta 1-\beta 3$ subunits, and one $\gamma 2$ subunit (Brünig et al., 2002; Michels and Moss, 2007; Olsen and Sieghart, 2009; Kasugai et al., 2010). We used cell-surface immunostaining to determine whether TNF $\alpha$ preferentially endocytoses certain receptor subtypes (Fig. 2A). $\mathrm{TNF} \alpha$ treatment ( $100 \mathrm{ng} / \mathrm{ml}, 45 \mathrm{~min}$ ) reduced the surface cluster area of $\alpha 1, \alpha 2, \beta 2 / 3$, and $\gamma 2$ subunits by $25-30 \%$ compared with untreated Ctrl cells $(\alpha 1,75.9 \pm 4.7 \%$ of Ctrl; $\alpha 2,71.4 \pm 1.5 \%$ of Ctrl; $\beta 2 / 3,71.7 \pm 2.3 \%$ of Ctrl; $\gamma 2,69.7 \pm 2.1 \%$ of Ctrl; Fig. $2 B$ ). There was no obvious difference in the specificity of the effect among these subunits, likely because they are trafficked in tandem as common components of synaptically localized receptors. Consistent with previous reports (Fritschy et al., 1994; Brünig et al., 2002), we observed a differential basal expression of the $\alpha 1$ subunit, with $\sim 20 \%$ of cells expressing markedly higher levels of surface $\alpha 1$ subunit in our cultures. Consequently, we independently assessed the effects of TNF $\alpha$ on cells expressing high levels of the $\alpha 1$ subunit. We found that levels of surface $\alpha 1$ on high expressors were unaltered after TNF $\alpha$ treatment $(102.1 \pm 3.5 \%$ of Ctrl), suggesting that $\alpha 1$ high expressors define a subset of neurons unresponsive to TNF $\alpha$. Previous reports have suggested that, in the hippocampus, higher expression of the $\alpha 1$ subunit is observed in interneurons (Fritschy et al., 1994; Brünig et al., 2002; Yu et al., 2006); however, based on colabeling of $\alpha 1$ and GAD, we observed that only $\sim 13 \%$ of high $\alpha 1$-expressing cells also expressed GAD, indicating that high $\alpha 1$-expressing cells in our cultures consisted of a mixed population of GABAergic interneurons and other cell types.

We also assessed the effects of TNF $\alpha$ treatment on surface levels of $\alpha 5$ subunit-containing receptor clusters, which are mainly located at extrasynaptic sites and primarily mediate tonic inhibition (Brünig et al., 2002; Caraiscos et al., 2004; Prenosil et al., 2006). We observed a much smaller but significant decrease in surface $\alpha 5$ cluster area ( $92.4 \pm 1.98 \%$ of Ctrl; Fig. 2B), suggesting that tonic inhibition mediated by $\alpha 5$-containing receptors may not be reduced as robustly as phasic inhibition.

To further determine whether TNF $\alpha$ exerts its effects by increasing receptor endocytosis rather than by solely reducing receptor clustering, we used cell-surface biotinylation assays to measure cell-surface levels of GABA ${ }_{\mathrm{A}} \mathrm{R} \beta 3$ (Fig. 2C,D). TNF $\alpha$ treatment $(100 \mathrm{ng} / \mathrm{ml}, 45 \mathrm{~min})$ decreased surface $\mathrm{GABA}_{\mathrm{A}} \mathrm{R} \beta 3$ without affecting total levels (surface, $70.8 \pm 12.9 \%$ of Ctrl; total, $99.3 \pm 15.5 \%$ of $\mathrm{Ctrl}$ ), providing additional evidence for increased receptor endocytosis. 
A
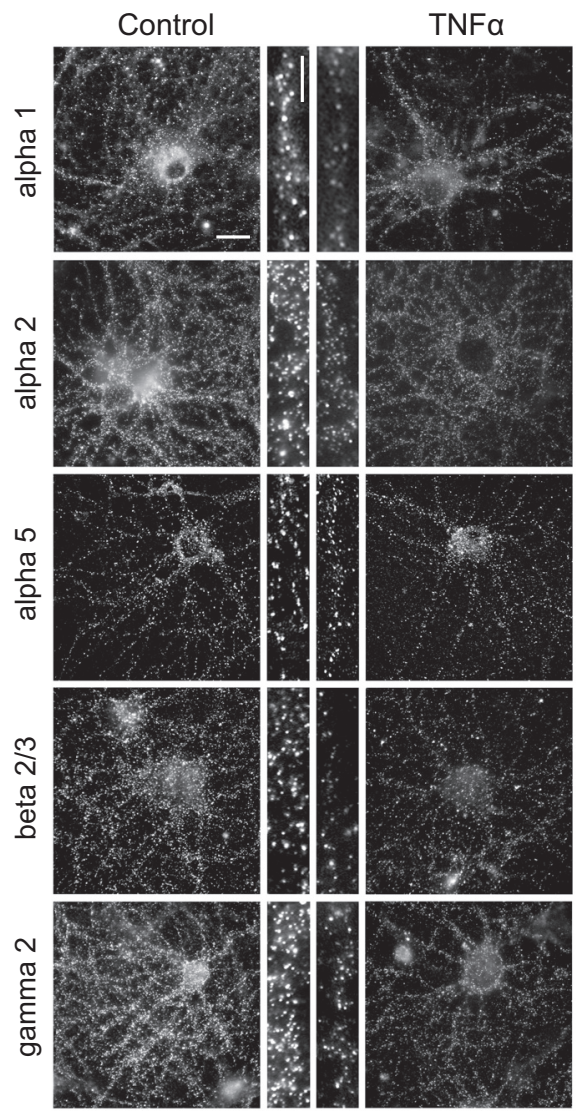

Figure 2. TNF $\alpha$ downregulates cell-surface levels of $\mathrm{GABA}_{A} \mathrm{Rs}$. $\boldsymbol{A}$, Representative images of surface immunostaining for $\alpha 1, \alpha 2, \alpha 5, \beta 2 / 3$, and $\gamma 2$ GABA $\mathrm{R}_{\mathrm{A}} \mathrm{subunits}$ in untreated (Control) and TNF $\alpha$-treated ( $100 \mathrm{ng} / \mathrm{ml}, 45 \mathrm{~min}$ ) cultures. Scale bars: low magnification, $20 \mu \mathrm{m}$; high magnification, $3 \mu \mathrm{m}$. $\boldsymbol{B}$, Quantification data of subunit cluster area corresponding to subunits represented in $\boldsymbol{A}$, showing a significant reduction in surface $\mathrm{GABA}_{\mathrm{A}} \mathrm{Rs}$ in response to TNF $\alpha$ treatment (gray bars), for all subunits examined $\left(\alpha 1, n=119-120,{ }^{* *} p<0.01 ; \alpha 2, n=189-261,{ }^{* * *} p<0.001\right.$; $\alpha 5, n=110-116,{ }^{*} p<0.05 ; \beta 2 / 3, n=210-258,{ }^{* * *} p<0.001 ; \gamma 2, n=316-420,{ }^{* * *} p<0.001 ;$ all comparisons by two-tailed Student's $t$ test). C, Representative Western blots of surface biotinylation assays comparing control and TNF $\alpha$-treated ( $100 \mathrm{ng} / \mathrm{ml}, 45 \mathrm{~min}$ ) cultures. $D$, Quantification of surface biotinylation assays showing a decrease in surface GABA $\mathrm{R} \beta 3 \mathrm{ffter}$ TNF $\alpha$ treatment but no change in total $\beta 3$ levels ( $n=11$ independent experiments; Mann-Whitney U test, ${ }^{*} p<0.05$ ).

\section{A reduction of gephyrin clustering follows the reduction of surface $\mathrm{GABA}_{\mathrm{A}} \mathrm{Rs}$ in response to TNF $\alpha$}

Next, we determined whether the effects of TNF $\alpha$ on $G_{A B A} R$ trafficking persisted over a short time course and whether other functionally important components of the GABAergic synapse were also altered over this time course. Using cell-surface immunostaining, we observed that surface $\mathrm{GABA}_{\mathrm{A}} \mathrm{R} \gamma 2$ cluster area gradually decreased in the presence of $\mathrm{TNF} \alpha$, reaching a minimum at $3 \mathrm{~h}(62.0 \pm 3.3 \%$ of Ctrl $)$, followed by a partial recovery at $6 \mathrm{~h}(79.5 \pm 4.4 \%$ of Ctrl; Fig. $3 A, B)$. This indicated that the effects of TNF $\alpha$ were rapid and persistent but that a recovery may eventually occur, possibly as a result of ligand-induced TNFR internalization (Mosselmans et al., 1988; Higuchi and Aggarwal, 1994) or proteolytic degradation of the exogenously supplied TNF $\alpha$ (Vey et al., 1996). To determine whether over this time course TNF $\alpha$ reduces surface levels of $\mathrm{GABA}_{\mathrm{A}}$ Rs by mechanisms other than receptor trafficking (e.g., via reduced receptor protein synthesis or increased receptor degradation), we measured total levels of $\mathrm{GABA}_{\mathrm{A}} \mathrm{R} \beta 3$ after 3 and 6 h of TNF $\alpha$ treatment. We observed no significant differences compared with untreated control cells (TNF $\alpha$ at $100 \mathrm{ng} / \mathrm{ml}$ for $3 \mathrm{~h}, 97.0 \pm 0.8 \%$ of Ctrl; TNF $\alpha$ at $100 \mathrm{ng} / \mathrm{ml}$ for $6 \mathrm{~h}, 96.8 \pm 3.5 \%$ of Ctrl; $n=3$ independent experiments; Kruskal-Wallis one-way ANOVA, $p=0.24$ ).

We hypothesized that exposure to TNF $\alpha$ may also affect clustering of gephyrin - a postsynaptic scaffolding protein present at most inhibitory synapses (Tretter et al., 2012). Multiple lines of evidence indicate that gephyrin contributes significantly to the stabilization of $\mathrm{GABA}_{\mathrm{A}} \mathrm{Rs}$ at postsynaptic sites (Kneussel et al., 1999; Lévi et al., 2004; Yu et al., 2007; Tretter et al., 2008; Mukherjee et al., 2011). We observed a significant downregulation of gephyrin cluster area at $3 \mathrm{~h}(84.5 \pm 4.1 \%$ of Ctrl $)$ and $6 \mathrm{~h}(66.6 \pm$ $3.2 \%$ of Ctrl) of TNF $\alpha$ treatment, whereas shorter treatments of 10 and 45 min elicited only small, nonsignificant decreases $(96.4 \pm 3.6 \%$ of Ctrl at $10 \mathrm{~min} ; 93.0 \pm 4.2 \%$ of Ctrl at $45 \mathrm{~min}$; Fig. $3 A, C)$. This effect was primarily attributable to reduced cluster density $(100.3 \pm 3.5 \%$ of Ctrl at $10 \mathrm{~min} ; 95.7 \pm 4.2 \%$ of Ctrl at 45 min; $85.2 \pm 3.9 \%$ of Ctrl at $3 \mathrm{~h} ; 70.1 \pm 1.2 \%$ of Ctrl at $6 \mathrm{~h}$ ) rather than reduced average cluster size $(96.4 \pm 1.2 \%$ of Ctrl at $10 \mathrm{~min}$; $97.5 \pm 1.5 \%$ of Ctrl at $45 \mathrm{~min} ; 99.5 \pm 3.3 \%$ of Ctrl at $3 \mathrm{~h} ; 95.7 \pm$ $2.4 \%$ of Ctrl at $6 \mathrm{~h}$ ). Together, these findings suggest that $\mathrm{GABA}_{\mathrm{A}} \mathrm{R}$ clusters are initially lost mainly as a result of endocytosis but that, after longer exposures to TNF $\alpha(>3 \mathrm{~h})$, a reduction in gephyrin clustering may also destabilize synaptic $\mathrm{GABA}_{\mathrm{A}} \mathrm{Rs}$.

Because we observed a decrease in mIPSC frequency (Fig. 1C), we asked whether correlates of GABA synthesis or the number of GABA release sites could be altered by $\operatorname{TNF} \alpha$. To address this possibility, we immunostained for GAD65-the rate-limiting enzyme in the production of GABA from glutamate at nerve terminals (Buddhala et al., 2009). GAD65 is aggregated in puncta at inhibitory presynaptic terminals and its expression is subject to activity-dependent homeostatic regulation (Rannals and Kapur, 2011; Lau and Murthy, 2012). Over the same $6 \mathrm{~h}$ time course of 
A TNFa

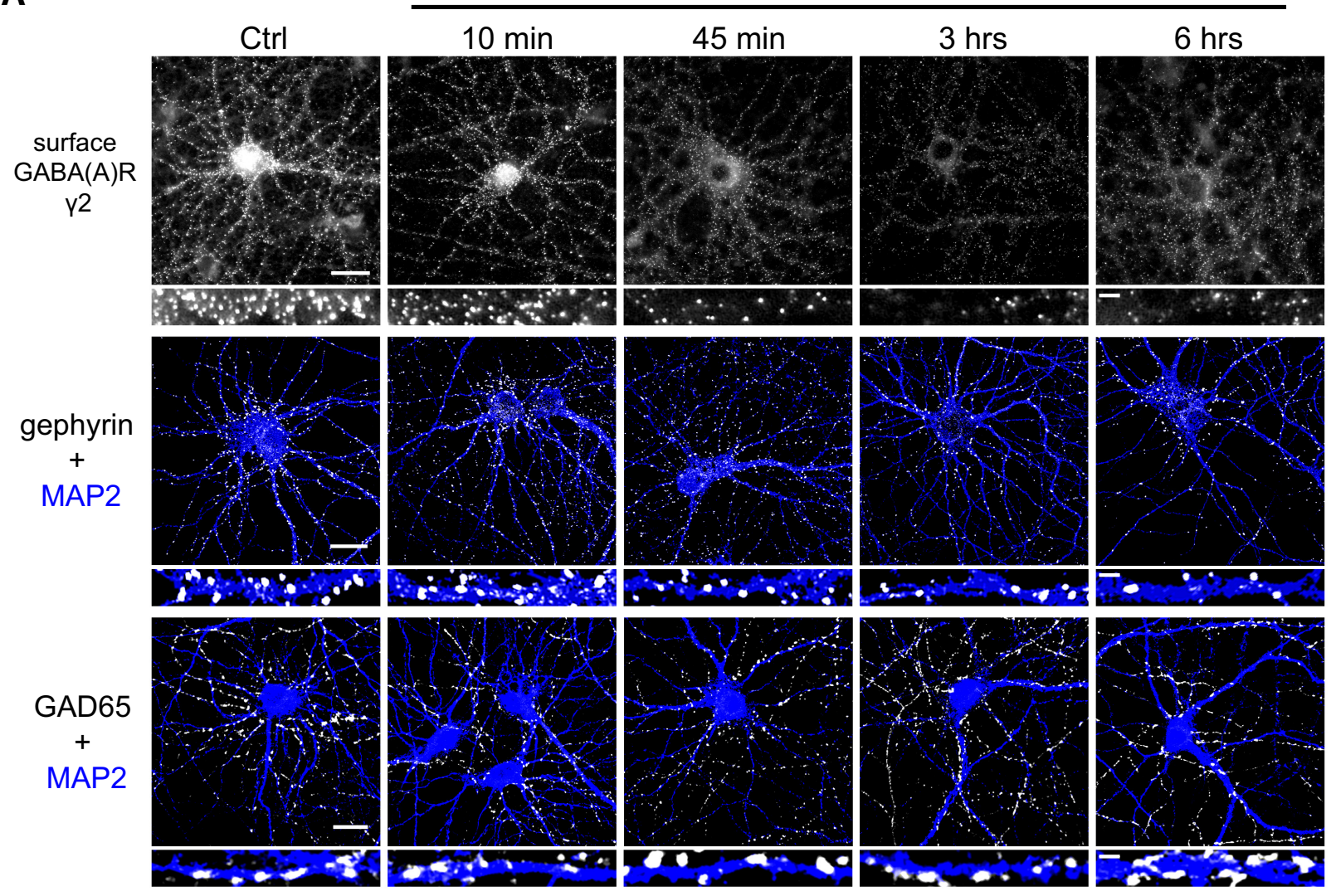

B

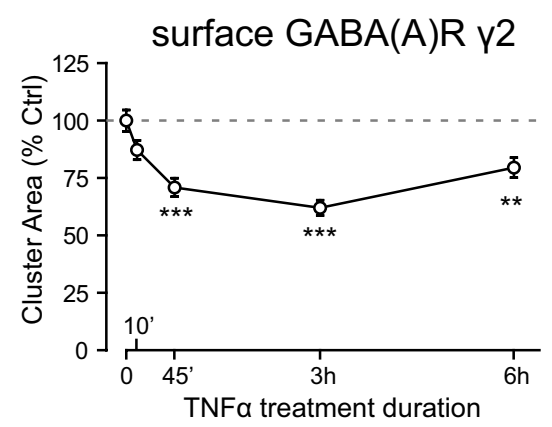

\section{C}

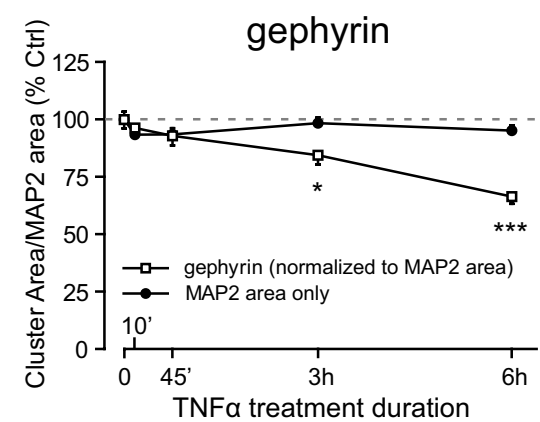

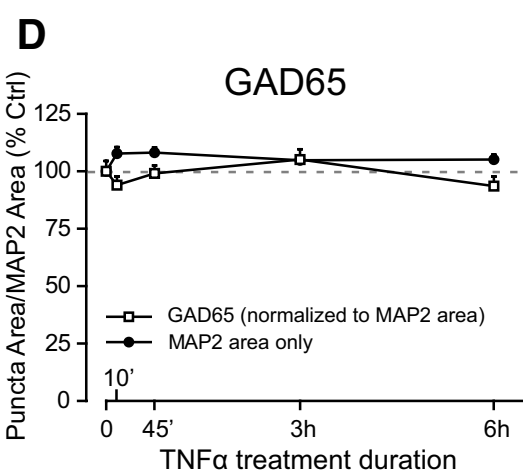

Figure 3. TNF $\alpha$-induced downregulation of surface $\mathrm{GABA}_{A}$ Rs precedes a downregulation of gephyrin clustering, with no change in GAD65 puncta. $A$, Representative images from time course experiments with cultured neurons undergoing TNF $\alpha$ treatment ranging from $10 \mathrm{~min}$ to $6 \mathrm{~h}$ in duration. Top row shows a rapid downregulation in surface levels of the $\gamma 2$ subunit in response to TNF $\alpha$. Middle row represents a matching set of experiments in which cells were permeabilized and immunostained for gephyrin (white) and MAP2 (blue), showing a slower downregulation of cluster area than for $\gamma 2$. Bottom row represents another matching set of experiments in which cells were permeabilized and immunostained for GAD65 (white) and MAP2 (blue), showing no change in puncta area. Scale bars: low magnification, $20 \mu \mathrm{m}$; high magnification, $1.5 \mu \mathrm{m}$. B, Quantification data of surface $\gamma 2$ cluster area, over the $6 \mathrm{~h}$ time course of TNF $\alpha$ treatment ( $n=120-158$ images per time point; one-way ANOVA, Tukey's post hoc test, $\left.{ }^{* *} p<0.01,{ }^{* * *} p<0.001\right)$. C, Quantification data of gephyrin cluster area normalized to MAP2 area (white boxes). MAP2 area (dark circles) was unaltered ( $n=65-82$ images per time point; one-way ANOVA, Tukey's post hoc test, ${ }^{*} p<0.05$, ${ }^{* * *} p<0.001$ ). D, Quantification data of GAD65 puncta area normalized to MAP2 area (white boxes). MAP2 area (dark circles) was unaltered ( $n=80-112$ images per time point; one-way ANOVA, Tukey's post hoc test, no significant differences).

TNF $\alpha$ treatment as for surface $\mathrm{GABA}_{\mathrm{A}} \mathrm{R} \gamma 2$ and gephyrin, we observed no significant changes in GAD65 puncta area (95.1 \pm $3.8 \%$ of Ctrl at $10 \mathrm{~min} ; 99.4 \pm 3.3 \%$ of Ctrl at $45 \mathrm{~min} ; 105.3 \pm$ $4.4 \%$ of Ctrl at $3 \mathrm{~h} ; 94.6 \pm 4.1 \%$ of Ctrl at $6 \mathrm{~h}$; Fig. $3 A, D$ ), nor any significant changes in puncta density $(95.9 \pm 3.6 \%$ of Ctrl at 10 min; $106.2 \pm 3.7 \%$ of Ctrl at $45 \mathrm{~min} ; 114.1 \pm 4.6 \%$ of Ctrl at $3 \mathrm{~h}$; $105.7 \pm 4.7 \%$ of Ctrl at $6 \mathrm{~h})$ or average puncta size $(102.0 \pm 2.5 \%$ of Ctrl at $10 \mathrm{~min} ; 97.9 \pm 2.3 \%$ of Ctrl at $45 \mathrm{~min} ; 95.0 \pm 1.9 \%$ of Ctrl at $3 \mathrm{~h} ; 94.1 \pm 2.4 \%$ of Ctrl at $6 \mathrm{~h}$ ). Therefore, the mIPSC frequency decrease caused by TNF $\alpha$ is unlikely to be due to a decrease in the number of GABA release sites. As well, because average puncta size was not affected, TNF $\alpha$ does not appear to affect the production of GABA at synaptic sites.

We costained for MAP2 to normalize gephyrin and GAD65 measurements to somatodendritic area, as well as to assess somatodendritic integrity over a prolonged exposure to TNF $\alpha$. We observed no significant differences in MAP2 area in either set of experiments (Fig. 3C,D, plotted as "MAP2 area only"), indicating that TNF $\alpha$ does not exert any overt deleterious effects on neuronal structure and integrity under our conditions. 
TNF $\alpha$ signals through neuronal TNFR1, p38 MAPK, PI3K, and PP1 to downregulate surface $G_{A B A_{A}} R$ levels and GABAergic neurotransmission

To identify signal transduction mechanisms, we first examined the relative contribution of TNFR1 versus TNFR2 signaling to TNF $\alpha$-dependent $\mathrm{GABA}_{\mathrm{A}} \mathrm{R}$ trafficking. Both TNFRs are constitutively expressed throughout the CNS by neurons and glia (Dopp et al., 1997; Zhang et al., 2010; Brambilla et al., 2011). Knowing that AMPAR trafficking in response to TNF $\alpha$ occurs via neuronal TNFR1 (Stellwagen et al., 2005; He et al., 2012) and that soluble TNF $\alpha$ preferentially signals through TNFR1 (McCoy and Tansey, 2008), we predicted that TNFR1 would be required in this case. Indeed, when selectively blocking either TNFR1 or TNFR2 using neutralizing antibodies, we observed that blockade of TNFR1 signaling prevented the TNF $\alpha$-induced downregulation of surface GABA ${ }_{\mathrm{A}} \mathrm{R} \gamma 2$ cluster area $(109.2 \pm 4.7 \%$ of TNFR1 control), whereas blockade of TNFR2 did not $(81.4 \pm 4.0 \%$ of TNFR2 control; Fig. $4 A, B)$. Because TNF $\alpha$ can also control the release of glutamate from astrocytes (Domercq et al., 2006; Santello et al., 2011), we assessed whether the effect occurred via direct activation of neuronally expressed TNFR1 or via glial TNFR1 activation followed by release of a glial factor that would control $\mathrm{GABA}_{\mathrm{A}} \mathrm{R}$ trafficking. To this end, we prepared Banker cocultures (Kaech and Banker, 2006) using WT or TNFR1 ${ }^{-/-}$glial feeder layers in combination with either WT or TNFR1 ${ }^{-1-}$ neurons. When using a WT glial feeder layer, mIPSC amplitude was reduced in WT neurons after TNF $\alpha$ treatment (Ctrl, $59.5 \pm 5.2 \mathrm{pA} ; \mathrm{TNF} \alpha, 31.4 .0 \pm 3.6 \mathrm{pA})$ but was unaffected in TNFR1 ${ }^{-1-}$ neurons (Ctrl, $59.3 \pm 7.1 \mathrm{pA}$; TNF $\alpha, 58.2 \pm 4.0 \mathrm{pA}$; Fig. $4 C, D)$. When using a TNFR $1^{-1-}$ glial feeder layer, we still observed a reduction in mIPSCs recorded from WT neurons (Ctrl, $56.7 \pm 3.6$ pA; TNF $\alpha, 36.8 \pm 3.2$ pA; Fig. $4 C, D$ ). Therefore, we conclude that neuronal TNFR1 controls $G_{A B A} R$ trafficking.

Signal transduction via TNFR1 involves assembly of adaptor proteins in a signaling complex around the intracellular "death domain" of the receptor, resulting in activation of various downstream targets and various cellular responses, depending on cell type and cell state (Sriram and O'Callaghan, 2007; McCoy and Tansey, 2008; Zhang et al., 2009). However, little is known about the intracellular substrates of TNFR1 that control receptor trafficking in neurons; only PI3K is known to be required for increasing surface levels of AMPARs (Stellwagen et al., 2005). Therefore, using pharmacological inhibitors, we sought to identify such signaling components, aiming to find a link between TNF $\alpha$ signaling and mechanisms mediating $\mathrm{GABA}_{\mathrm{A}} \mathrm{R}$ endocytosis. Given the rapid effects of TNF $\alpha$ on surface levels of $\mathrm{GABA}_{\mathrm{A}} \mathrm{Rs}$, we focused on inhibitors of kinases and phosphatases known to regulate $\mathrm{GABA}_{\mathrm{A}} \mathrm{R}$ trafficking (Luscher et al., 2011) or known to be downstream of TNFR1 (Grivennikov et al., 2006; Zhang et al., 2010). We found that blocking PKA (with KT 5720) or PKC (with Gö 6983)—kinases that phosphorylate $\mathrm{GABA}_{\mathrm{A}} \mathrm{Rs}$ (McDonald et al., 1998; Brandon et al., 2000, 2003) — did not alter the effects of TNF $\alpha$ (KT 5720 alone, $100.0 \pm 3.9 \%$ of DMSO alone; KT $5720+$ TNF $\alpha, 59.1 \pm 2.8 \%$ of DMSO alone; Gö 6983 alone, $100.0 \pm$ $6.6 \%$ of DMSO alone; Gö $6983+\mathrm{TNF} \alpha, 73.7 \pm 3.3 \%$ of DMSO alone; Fig. $5 A, B)$. However, preincubation with inhibitors of PI3K (wortmannin) or p38 MAPK (SB 202190) blocked the TNF $\alpha$-induced reduction in surface $\gamma 2$ subunit cluster area (wortmannin alone, $73.5 \pm 5.4 \%$ of DMSO alone; wortmannin $+\mathrm{TNF} \alpha, 83.1 \pm 3.9 \%$ of DMSO alone; SB 202190 alone, $68.3 \pm 6.6 \%$ of DMSO alone; SB $202190+$
A

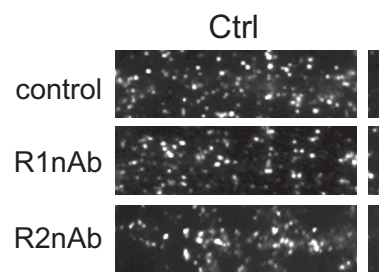

TNFa

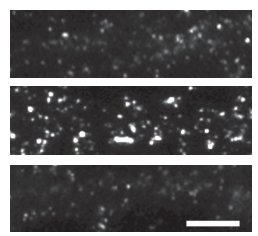

B

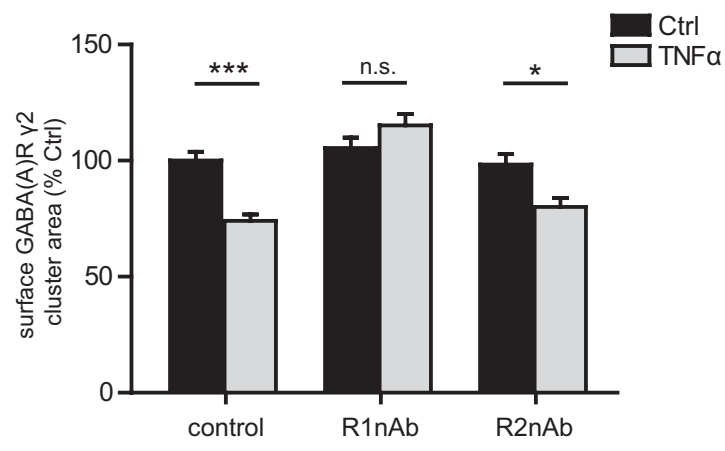

C Ctrl TNFa
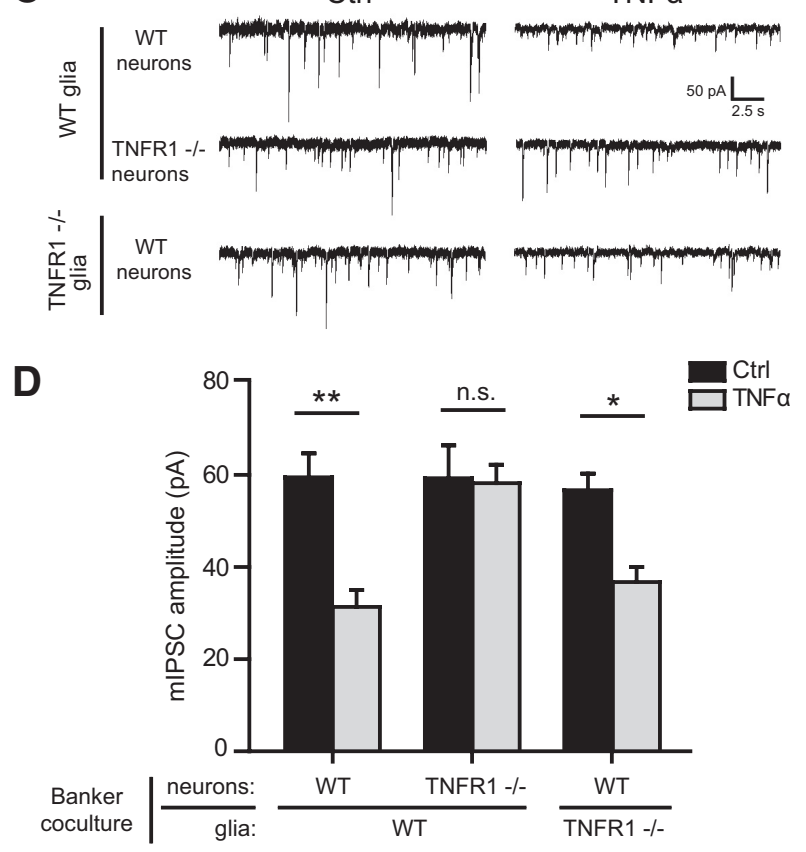

Figure 4. TNF $\alpha$ signals through neuronal TNFR1 to downregulate GABAergic neurotransmission. $A$, Representative dendritic regions of surface immunostaining for $G A B A_{A} R \gamma 2$ subunit, from untreated (Ctrl) or TNF $\alpha$-treated cultured neurons, preincubated with either TNFR1 neutralizing antibody (R1nAb) or TNFR2 neutralizing antibody (R2nAb). Scale bar, $3 \mu \mathrm{m}$. B, Quantification data of $\gamma 2$ cluster area corresponding to conditions in $A$, showing that blocking TNFR1 function blocks the effects of TNF $\alpha$ (gray bars), whereas blocking TNFR2 does not ( $n=135$ 191 images in each condition; two-way ANOVA, Bonferroni's post hoc test, ${ }^{*} p<0.05,{ }^{* * *} p<$ 0.001 ; n.s., not significant). C, Representative traces of mIPSC recordings from untreated (Ctrl) or TNF $\alpha$-treated WT or TNFR $1^{-1-}$ neurons cocultured with WT glia or TNFR1 ${ }^{-/}$glia. D, Group data of average mIPSC amplitude indicating that TNF $\alpha$-induced downregulation is absent from TNFR1 $1^{-1-}$ neurons cocultured with WT glia but present in WT neurons cocultured with WT or TNFR1 ${ }^{-1-}$ glia ( $n=12-22$ cells in each condition; two-way ANOVA, Bonferroni's post hoc test, ${ }^{*} p<0.05,{ }^{* *} p<0.01$; n.s., not significant).

TNF $\alpha, 71.7 \pm 4.1 \%$ of DMSO alone; Fig. $5 A, B)$. Because wortmannin alone and SB 202190 alone reduced $\gamma 2$ cluster area, it is not clear whether an additional decrease in response to TNF $\alpha$ was occluded in these cases. We targeted PP1 and PP2A 

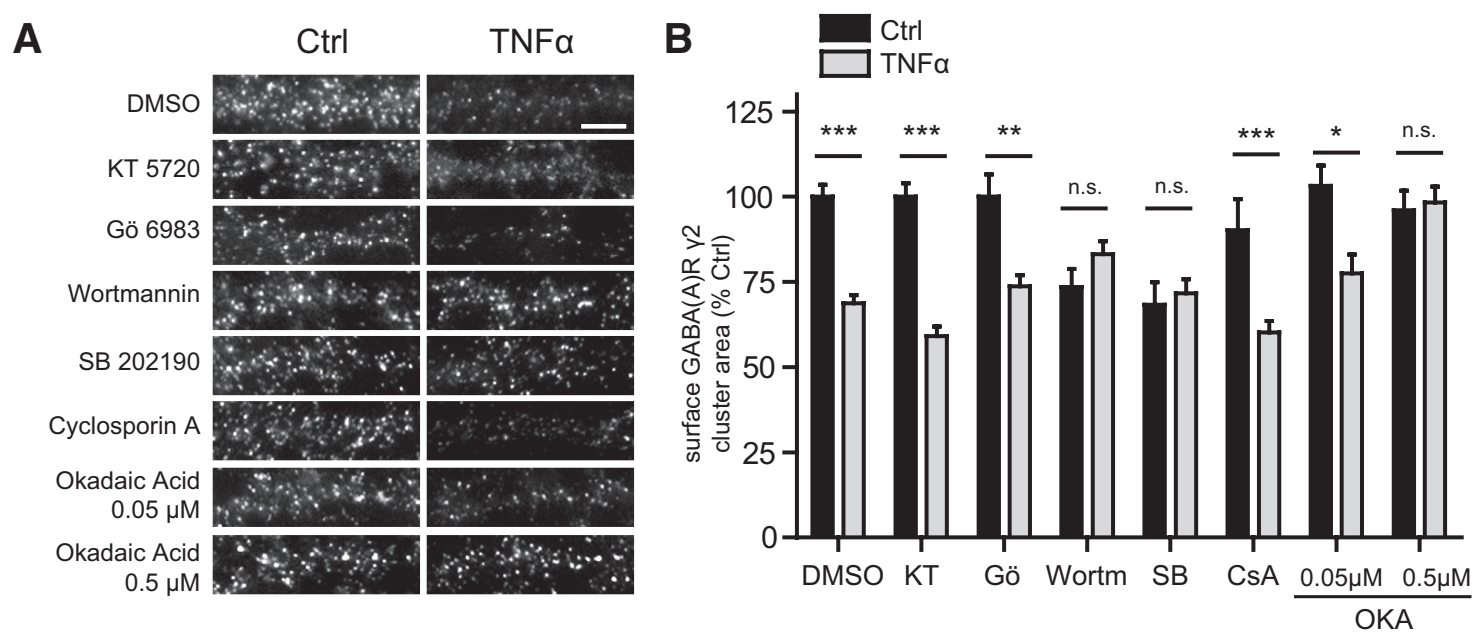

Figure 5. Downregulation of surface GABA $R$ $\gamma 2$ levels in response to TNF $\alpha$ is blocked by inhibitors of PI3K, $\mathrm{p} 38 \mathrm{MAPK}$, and PP1/PP2A. $A$, Representative dendritic regions of surface immunostaining for $G_{\text {GABA }} R \gamma 2$ subunit, from control (Ctrl) versus TNF $\alpha$-treated ( $100 \mathrm{ng} / \mathrm{ml}, 45 \mathrm{~min}$ ) cultured neurons, preincubated with DMSO (solvent, 0.1\%) or inhibitors of PKA [KT 5720 (KT), $1 \mu \mathrm{m}$ ], PKC [Gö 6983 (Gö), $1 \mu \mathrm{m}$ ], PI3K [wortmannin (Wortm), $100 \mathrm{~nm}$ ], p38 MAPK [SB 202190 (SB), $10 \mu \mathrm{m}$ ], calcineurin [cyclosporin A (CSA), $20 \mu \mathrm{m}$ ], and PP1/PP2A (okadaic acid (0KA), 0.05 or $0.5 \mu \mathrm{m}$ ). Scale bar, $3 \mu \mathrm{m} . \boldsymbol{B}$, Quantification data corresponding to conditions in $A$, indicating that TNF $\alpha$-induced downregulation of surface $\gamma 2$ cluster area is blocked by preincubation with wortmannin, SB 2022190, and $0.5 \mu \mathrm{m}$ okadaic acid but not KT 5720 , Gö 6983, cyclosporin A, or $0.05 \mu$ m okadaic acid ( $n=60$-228 images in each condition; two-way ANOVA, Bonferroni's post hoc test, ${ }^{*} p<0.05$, ${ }^{* *} p<0.01$, ${ }^{* * *} p<0.001$; n.s., not significant).

using two different concentrations of okadaic acid ( 0.05 vs 0.5 $\mu \mathrm{M})$, because lower concentrations are known to preferentially block PP2A, whereas higher concentrations also block PP1 (Cohen et al., 1989; Surmeier et al., 1995; Suh et al., 2013). Interestingly, we found that we could block the effect of TNF $\alpha$ with $0.5 \mu \mathrm{M}$ okadaic acid but not with $0.05 \mu \mathrm{M}$, suggesting that PP1 but not PP2A is required $(0.05 \mu \mathrm{M}$ okadaic acid alone, $103.2 \pm 5.9 \%$ of DMSO alone; $0.05 \mu \mathrm{M}$ okadaic acid $+\mathrm{TNF} \alpha$, $77.5 \pm 5.5 \%$ of DMSO alone; $0.5 \mu \mathrm{M}$ okadaic acid alone, $96 \pm$ $5.8 \%$ of DMSO alone; $0.5 \mu \mathrm{M}$ okadaic acid $+\mathrm{TNF} \alpha, 98.3 \pm$ $4.7 \%$ of DMSO alone; Fig. $5 A, B$ ). Lastly, we found that calcineurin activity (blocked with cyclosporin A) was not required in this signaling pathway (cyclosporin A alone, 90.2 \pm $9.1 \%$ of DMSO alone; cyclosporin A $+\mathrm{TNF} \alpha, 60.2 \pm 3.3 \%$ of DMSO alone). Because PP1/PP2A activity has been implicated previously in $\mathrm{GABA}_{\mathrm{A}} \mathrm{R}$ endocytosis (Jovanovic et al., 2004; Kanematsu et al., 2006, 2007; Lin et al., 2011) whereas calcineurin activity has been implicated in $\mathrm{GABA}_{\mathrm{A}} \mathrm{R}$ cluster dispersal (Bannai et al., 2009; Muir et al., 2010), our findings are again consistent with an endocytosis-dependent effect.

To define which phosphatase is required for TNF $\alpha$-dependent trafficking of synaptic GABA ${ }_{\mathrm{A}}$ Rs, we assessed the effects of TNF $\alpha$ on mIPSC amplitude after simultaneous blockade of PP1 and PP2A (with $0.5 \mu \mathrm{M}$ okadaic acid) versus selective blockade of PP1 (with tautomycetin; Mitsuhashi et al., 2001) or PP2A (with fostriecin; Walsh et al., 1997). Consistent with immunostaining experiments, inhibition of PP1/PP2A blocked the TNF $\alpha$ induced decrease in mIPSC amplitude (DMSO alone, $56.8 \pm$ $3.9 \mathrm{pA} ; \mathrm{DMSO}+\mathrm{TNF} \alpha, 43.3 \pm 3.8 \mathrm{pA}$; okadaic acid alone, $62.3 \pm 4.7 \mathrm{pA}$; okadaic acid $+\mathrm{TNF} \alpha, 58.1 \pm 4.4 \mathrm{pA}$; Fig. $6 A, B)$. Selective inhibition of PP1 also blocked the effects of $\mathrm{TNF} \alpha$ (tautomycetin alone, $44.4 \pm 4.8 \mathrm{pA}$; tautomycetin + $\mathrm{TNF} \alpha, 55.4 \pm 4.0 \mathrm{pA}$ ), whereas selective inhibition of PP2A did not [dimethyl formamide (DMF) alone, $50.5 \pm 3.2 \mathrm{pA}$; $\mathrm{DMF}+\mathrm{TNF} \alpha, 35.2 \pm 2.2 \mathrm{pA}$; fostriecin alone, $51.3 \pm 5.1 \mathrm{pA}$; fostriecin $+\mathrm{TNF} \alpha, 32.5 \pm 2.8 \mathrm{pA}$ ]. Interestingly, the effects of TNF $\alpha$ on mIPSC frequency were reversed by okadaic acid and tautomycetin but unaffected by fostriecin (DMSO alone, $0.80 \pm 0.10 \mathrm{~Hz} ; \mathrm{DMSO}+\mathrm{TNF} \alpha, 0.59 \pm 0.07 \mathrm{~Hz}$; okadaic acid
A

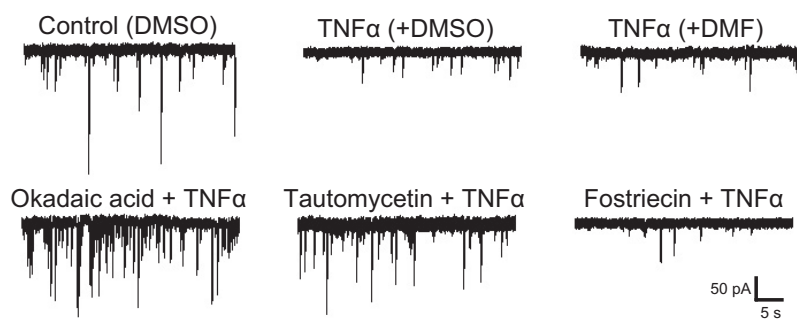

B

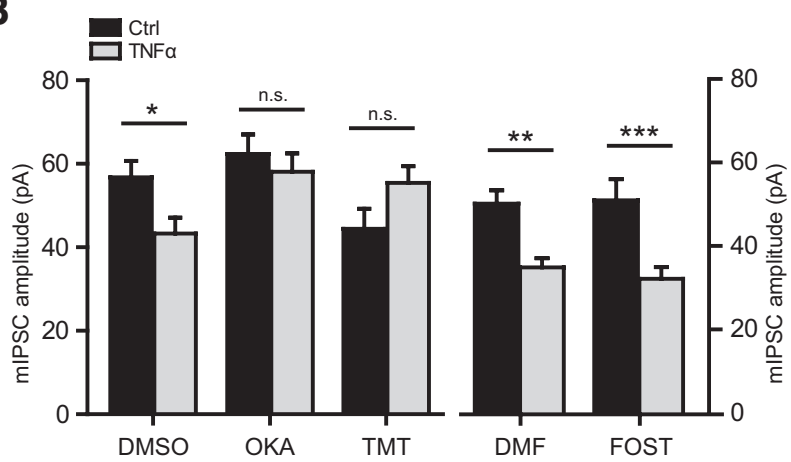

Figure 6. TNF $\alpha$ downregulates GABAergic neurotransmission through PP1 but not PP2A. $A$ mIPSCs were recorded from control or TNF $\alpha$-treated $(100 \mathrm{ng} / \mathrm{ml}, 45 \mathrm{~min})$ cultured neurons (preincubated with solvent alone or inhibitor). DMSO (0.1\%) was used as a solvent for okadaic acid (OKA) and tautomycetin (TMT); DMF (0.1\%) was used as a solvent for fostriecin (FOST). Shown are representative traces for control with DMSO preincubation, TNF $\alpha$-treated with DMSO or DMF preincubation, TNF $\alpha$-treated with okadaic acid preincubation (PP1/PP2A inhibitor, $0.5 \mu \mathrm{m}$ ), TNF $\alpha$-treated with tautomycetin preincubation (PP1 inhibitor, $10 \mathrm{nM}$ ), and TNF $\alpha$-treated with fostriecin preincubation (PP2A inhibitor, $10 \mathrm{~nm}$ ). $\boldsymbol{B}$, Group data of average mIPSC amplitudes for all conditions, showing that preincubation with okadaic acid or tautomycetin blocks the TNF $\alpha$-induced downregulation of mIPSC amplitude, whereas preincubation with fostriecin does not ( $n=16-25$ cells in each condition; two-way ANOVA, Bonferroni's post hoc test, ${ }^{*} p<0.05,{ }^{* *} p<0.01,{ }^{* * *} p<0.001$; n.s., not significant).

alone, $1.45 \pm 0.18 \mathrm{~Hz}$; okadaic acid $+\mathrm{TNF} \alpha, 1.79 \pm 0.23 \mathrm{~Hz}$; tautomycetin alone, $0.84 \pm 0.14 \mathrm{~Hz}$; tautomycetin $+\mathrm{TNF} \alpha$, $1.42 \pm 0.22 \mathrm{~Hz}$; DMF alone, $1.35 \pm 0.24 \mathrm{~Hz} ; \mathrm{DMF}+\mathrm{TNF} \alpha$, $0.84 \pm 0.19 \mathrm{~Hz}$; fostriecin alone, $1.39 \pm 0.21 \mathrm{~Hz}$; fostriecin + 
A

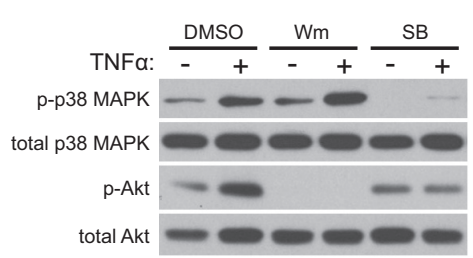

B

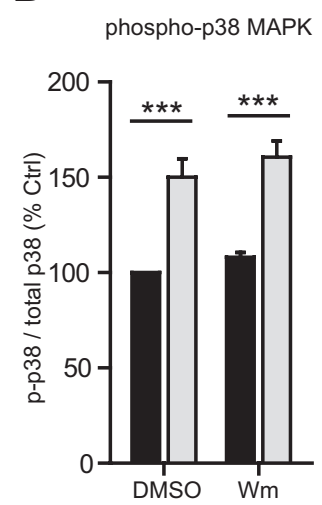

C

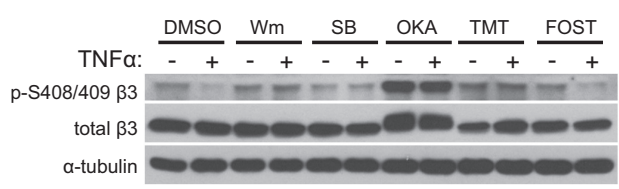

E

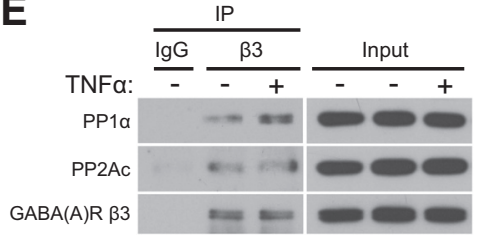

D

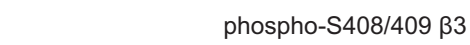

F

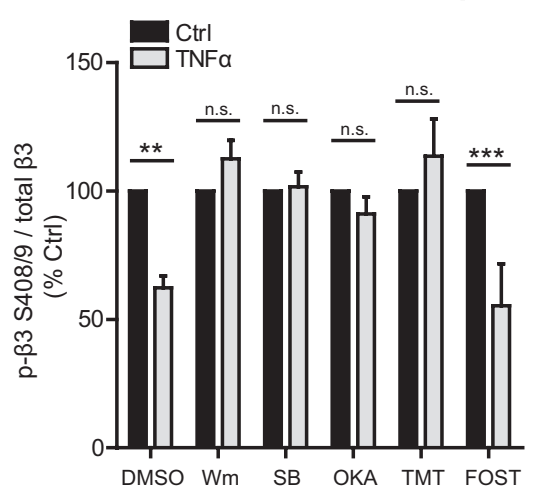

Figure 7. TNF $\alpha$ dephosphorylates GABA $\mathrm{R} \beta 3$ S408/409 by sequentially activating p38 MAPK and PI3K and enhancing the association of PP1 $\alpha$ with $\beta 3$ subunits. $\boldsymbol{A}$, Representative Western blots of phospho-p38MAPK, total p38MAPK, phospho-Akt, and total Akt in lysates from control or TNF $\alpha$-treated ( $100 \mathrm{ng} / \mathrm{ml}, 45 \mathrm{~min}$ ) cultures, preincubated with DMSO (solvent, $0.1 \%$ ) or inhibitors of PI3K [wortmannin $(\mathrm{Wm}), 100 \mathrm{~nm}$ ] and p38 MAPK [SB 202190 (SB), $10 \mu \mathrm{m}$ ]. B, Quantification data showing an increase in phospho-p38 MAPK with TNF $\alpha$ treatment, unaffected by PI3K inhibition (left), and an increase in phosphorylation of the PI3K downstream effector Akt, blocked by p38 MAPK inhibition (right) ( $n=4-5$ independent experiments; Mann-Whitney $U$ test, ${ }^{*} p<0.05$, ${ }^{* *} p<0.01$; .. ., not significant). $C$, Representative Western blots of phospho-S408/409 GABA $\mathrm{R} \beta 3$, total GABA $\mathrm{R} \beta 3$, and $\alpha$-tubulin in lysates from control or TNF $\alpha$-treated (100 ng/ml, 45 min) cultures, preincubated with DMSO (solvent, $0.1 \%$ ) or inhibitors of PI3K [wortmannin (Wm), 100 nm], p38 MAPK [SB 202190 (SB), $10 \mu \mathrm{m}$ ], PP1/PP2A [okadaic acid (0KA), $0.5 \mu \mathrm{m}$ ], PP1 [tautomycetin (TMT), 10 nm], and PP2A [fostriecin (FOST), 10 nM]. D, Quantification data showing a decrease in $\mathrm{GABA}_{\mathrm{A}} \mathrm{R} \beta 3$ phospho-S408/409, blocked by inhibition of PI3K, p38 MAPK, and PP1, but not by inhibition of PP2A ( $n=5$ independent experiments; Mann-Whitney U test, ${ }^{* *} p<0.01,{ }^{* * *} p<0.001$; n.S., not significant). $\boldsymbol{E}$, Representative Western blots of coimmunoprecipitation experiments in which the $\mathrm{GABA}_{\mathrm{A}} \mathrm{R} \beta 3$ subunit was immunoprecipitated (IP) from untreated (Ctrl) or TNF $\alpha$-treated (100 ng/ml, $30 \mathrm{~min}$ ) cultures; blots were then probed for GABA R $\beta 3$ and for the catalytic subunits of PP1 (PP1 $\alpha$ ) and PP2A (PP2Ac). F, Quantification showing that TNF $\alpha$ treatment enhances the association of PP1 $\alpha$ but not PP2Ac with $\beta 3$ subunits ( $n=5-6$ independent experiments; Mann-Whitney $U$ test, ${ }^{* *} p<0.01$; n.s., not significant).

TNF $\alpha, 0.78 \pm 0.13 \mathrm{~Hz}$ ). We conclude that TNF $\alpha$ downregulates GABAergic neurotransmission through PP1 but not PP2A activity.

TNF $\alpha$ dephosphorylates GABA $\mathrm{A} \beta 3$ S408/409 by sequentially activating $\mathrm{p} 38 \mathrm{MAPK}$ and $\mathrm{PI} 3 \mathrm{~K}$ while enhancing the association of PP1 $\alpha$ with $\beta 3$

To further characterize the signaling pathway linking neuronal TNFR1 to $\mathrm{GABA}_{\mathrm{A}} \mathrm{R}$ trafficking, we focused on the three molecular components we had identified using pharmacological inhibition: p38 MAPK, PI3K, and PP1. We used Western blots to assess activation of $\mathrm{p} 38$ and PI3K using antibodies specific for phosphop38 MAPK and phospho-Akt-a downstream target of PI3K activation. Phosphorylation of both p38 MAPK and Akt was significantly upregulated in response to TNF $\alpha(100 \mathrm{ng} / \mathrm{ml}, 45$ min; phospho-p38: DMSO + TNF $\alpha, 150.0 \pm 9.8 \%$ of DMSO alone; phospho-Akt: DMSO + TNF $\alpha, 182.5 \pm 34.6 \%$ of DMSO alone; Fig. $7 A, B$ ), indicating that both signaling components are activated. In addition, using pharmacological blockade of p38 MAPK (using SB 202190) or PI3K (using wortmannin), we determined that TNF $\alpha$-induced phosphorylation of p38 MAPK is unaffected by wortmannin (wortmannin alone, $108.0 \pm 2.6 \%$ of DMSO alone; wortmannin + TNF $\alpha, 160.5 \pm 8.5 \%$ of DMSO alone; Fig. $7 A, B)$, whereas TNF $\alpha$-induced phosphorylation of Akt is blocked by SB 202190 (SB alone, $83.5 \pm 12.5 \%$ of DMSO alone; $\mathrm{SB}+\mathrm{TNF} \alpha, 59.6 \pm 21.9 \%$ of DMSO alone; Fig. $7 A, B)$, indicating that p38 MAPK activation occurs upstream of PI3K activation in this signaling pathway.

Knowing that PP1 can localize to inhibitory synapses (Bausen et al., 2010) and that dephosphorylation of $\mathrm{GABA}_{\mathrm{A}} \mathrm{R} \beta 3$ should favor receptor endocytosis (Kittler et al., 2005; Smith et al., 2012), we hypothesized that PP1 acts downstream of p38 MAPK and PI3K to directly dephosphorylate $\mathrm{GABA}_{\mathrm{A}} \mathrm{R} \beta 3$. We assessed the phosphorylation state of $\beta 3$ subunits using a phospho-specific antibody detecting phosphorylated $\beta 3$ S408/409 (Fig. 7C). We focused on this site for two reasons. First, whereas other serine sites on $\mathrm{GABA}_{\mathrm{A}} \mathrm{Rs}$ (e.g., $\gamma 2 \mathrm{~S} 327$ ) are known to be regulated by calcineurin (Bannai et al., 2009; Muir et al., 2010), $\beta 3$ S408/409 is the only site known to be regulated by PP1 (for review, see Luscher et al., 2011). Second, this site is located in the $\beta 1-\beta 3$ intracellular domains, in a basic patch sorting motif that directly binds the $\mu 2$ subunit of the clathrin adaptor AP2 to mediate dynamin-dependent endocytosis (Kittler et al., 2005; Smith et al., 2012). Phosphorylation of this site disrupts the interaction with $\mu 2-\mathrm{AP} 2$ and increases synaptic $\mathrm{GABA}_{\mathrm{A}} \mathrm{R}$ content (Kittler et al., 2005). We observed a significant reduction in phospho-S408/409 in response to TNF $\alpha$ treatment $(100 \mathrm{ng} / \mathrm{ml}, 45 \mathrm{~min}$; DMSO + TNF $\alpha, 62.3 \pm 3.7 \%$ of DMSO alone; Fig. $7 C, D$ ), consistent with an increased rate of $\mathrm{GABA}_{\mathrm{A}} \mathrm{R}$ endocytosis and a loss of surface $\mathrm{GABA}_{\mathrm{A}} \mathrm{R} \beta 3$. However, pretreatment with either $0.5 \mu \mathrm{M}$ okadaic acid or tautomycetin, but not with fostriecin, blocked TNF $\alpha$ induced $\beta 3$ S408/409 dephosphorylation (Fig. 7C,D), indicating that this is a PP1-mediated dephosphorylation (okadaic acid + $\mathrm{TNF} \alpha, 91.0 \pm 6.7 \%$ of okadaic acid alone; tautomycetin + TNF $\alpha, 113.6 \pm 14.5 \%$ of tautomycetin alone; fostriecin $+\mathrm{TNF} \alpha$, $55.4 \pm 16.1 \%$ of fostriecin alone; Fig. $7 D$ ). Furthermore, inhibition of p38 MAPK or PI3K also blocked TNF $\alpha$-induced $\beta 3$ S408/ 409 dephosphorylation (Fig. 7C,D), indicating that activation of p38 MAPK and PI3K is required for receptor dephosphorylation 
(wortmannin $+\mathrm{TNF} \alpha, 112.5 \pm 7.2 \%$ of wortmannin alone; SB $202190+\mathrm{TNF} \alpha$, $101.6 \pm 5.8 \%$ of SB 202190 alone; Fig. 7D).

Previous studies have suggested that an increased abundance of protein phosphatase associated with the $\mathrm{GABA}_{\mathrm{A}} \mathrm{R}$ protein complex correlates with increased dephosphorylation of $\beta 3$ and subsequent endocytosis of $\mathrm{GABA}_{\mathrm{A}}$ Rs (Jovanovic et al., 2004; Kanematsu et al., 2006). The association of PP1 and PP2A with the $\beta 3$ subunit is facilitated by the adaptor/regulatory proteins PRIP-1 and PRIP-2, which selectively bind to the intracellular domains of $\beta 1-\beta 3$ subunits but not $\alpha 1-\alpha 3$ or $\gamma 2$ subunits (Terunuma et al., 2004; Kanematsu et al., 2006, 2007; Yanagihori et al., 2006). We used coimmunoprecipitation to determine whether the association of $\beta 3$ with the catalytic subunits of PP1 $(\mathrm{PP} 1 \alpha)$ or PP2A (PP2Ac) was regulated by $\mathrm{TNF} \alpha$ (Fig. $7 E, F)$. Consistent with mIPSC recordings showing a requirement of PP1 but not $\mathrm{PP} 2 \mathrm{~A}$ activity, we observed an increase in the association of $\mathrm{PP} 1 \alpha$ with $\beta 3$ but no change in the association of PP2Ac with $\beta 3$ (PP1 $\alpha$, $180.7 \pm 28.3 \%$ of Ctrl; PP2Ac, $94.6 \pm$ $13.1 \%$ of Ctrl; Fig. $7 F$ ). This suggests that, in response to $\mathrm{TNF} \alpha, \mathrm{PP} 1$ is targeted to the intracellular domain of the $\beta 3$ subunit, which may enable it to dephosphorylate key residues that regulate interactions with the endocytic machinery.

\section{A similar TNF $\alpha$ signaling pathway regulates $\mathrm{GABAergic}$ synapses in acute hippocampal slices}

To extend our findings from cultured hippocampal neurons to a more intact hippocampal preparation, we treated acute hippocampal slices from young adult mice with $\mathrm{TNF} \alpha(100 \mathrm{ng} / \mathrm{ml}, 1 \mathrm{~h})$ and assessed activation of the p38 MAPKPI3K- 33 S408/409 signaling pathway. In agreement with our results from culture experiments, we observed a significant increase in phospho-p38 MAPK (179.8 \pm $20.2 \%$ of Ctrl), a trend for increased phospho-Akt (144.3 $\pm 20.7 \%$ of Ctrl) and a significant decrease in $\beta 3 \mathrm{~S} 408 / 409$ phosphorylation $(68.6 \pm 8.9 \%$ of Ctrl; Fig. $8 A, B)$. Similarly, surface $\mathrm{GABA}_{\mathrm{A}} \mathrm{R} \beta 3$ was decreased $(67.5 \pm 12.9 \%$ of Ctrl $)$, whereas, in accordance with previous findings (Stellwagen et al., 2005), surface GluA1 was increased $(150.1 \pm 20.53 \%$ of Ctrl; Fig. $8 A, B)$. We observed no changes in total p38 MAPK, total Akt, total $\mathrm{GABA}_{\mathrm{A}} \mathrm{R} \beta 3$, or total GluA1 (p38 MAPK, $102.7 \pm 6.1 \%$ of Ctrl; Akt, $87.5 \pm 9.7 \%$ of Ctrl; $\beta 3,103.7 \pm 6.2 \%$ of Ctrl; GluA1, $108.9 \pm 9.4 \%$ of Ctrl; $n=8-9$ animals in each condition; Mann-Whitney $U$ test, $p>$ 0.05 for each). To determine whether in acute hippocampal slices $\mathrm{TNF} \alpha(100 \mathrm{ng} / \mathrm{ml},>1 \mathrm{~h})$ decreases synaptic $\mathrm{GABA}_{\mathrm{A}} \mathrm{R}$ content in a PP1-dependent manner, we recorded mIPSCs from CA1 pyramidal neurons, in slices pretreated with either DMSO or the PP10.01 ; n.s., not significant).
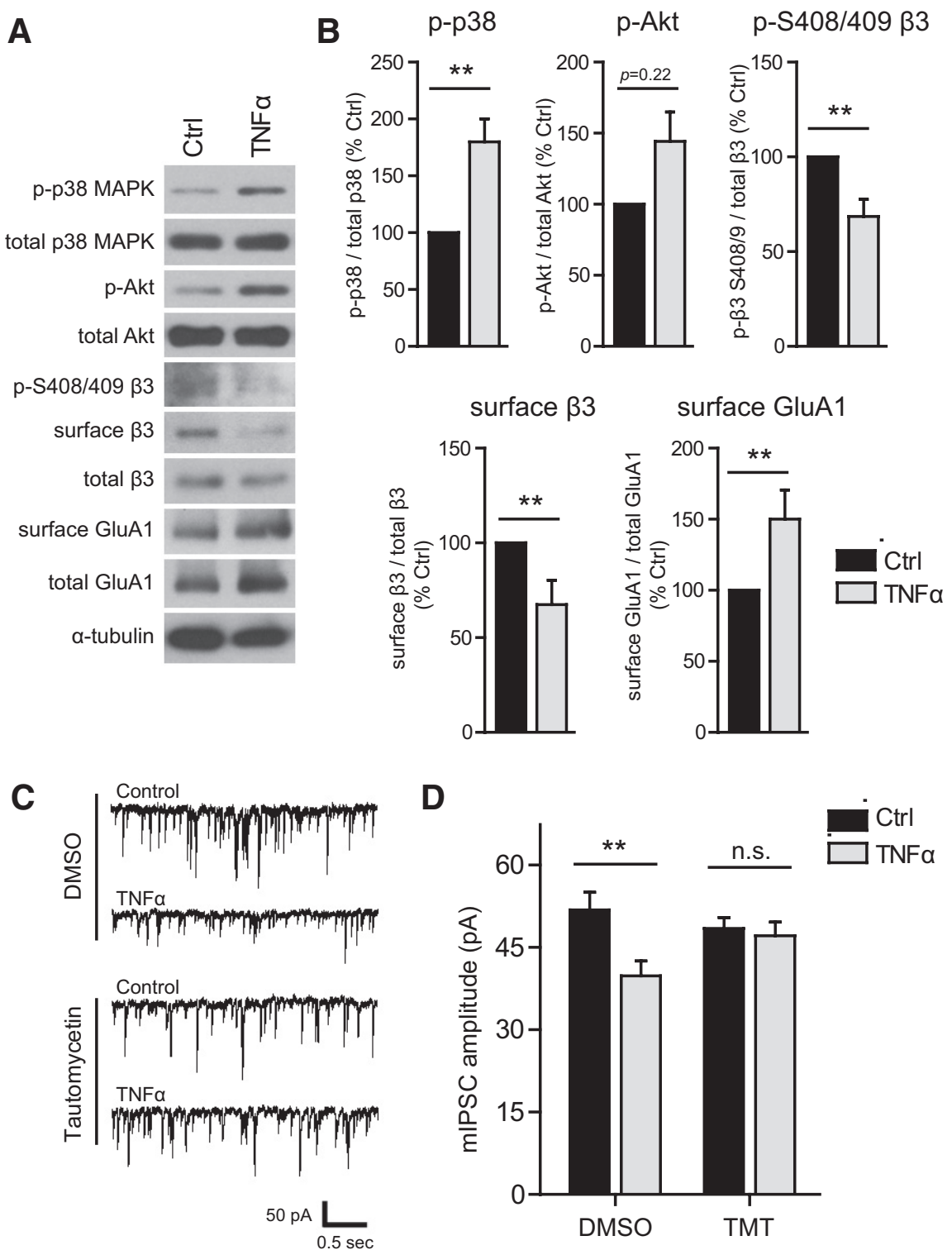

Figure 8. A similar TNF $\alpha$ signaling pathway regulates inhibitory synapses in acute hippocampal slices. $\boldsymbol{A}$, Representative Western blots of phospho-p38 MAPK, total p38 MAPK, phospho-Akt, total Akt, phospho-S408/409 GABA $R$ R $\beta 3$, surface (biotinylated) $G A B A_{A} R \beta 3$, total lysate $G_{A B A_{A} R} \beta 3$, surface (biotinylated) GluA1, total lysate GluA1, and $\alpha$-tubulin, from acute slices of mouse dorsal hippocampus, either untreated (Ctrl) or treated with TNF $\alpha(100 \mathrm{ng} / \mathrm{ml}, 1 \mathrm{~h})$. B, Quantification data corresponding to experiments represented in $\boldsymbol{A}$, showing a TNF $\alpha$-induced increase in phospho-p38 MAPK, an increase in phospho-Akt, a decrease in phospho- $5408 / 409 \beta 3$, a decrease in surface levels of $G_{A B A_{A}} R \beta 3$, and an increase in surface levels of $\mathrm{GluA} 1$ ( $n=8-9$ animals in each condition; Mann-Whitney $U$ test, $\left.{ }^{* *} p<0.01\right)$. C, Sample traces of mIPSCs recorded from acute hippocampal slice CA1 pyramidal neurons, either control or TNF $\alpha$-treated $(100 \mathrm{ng} / \mathrm{ml},>1 \mathrm{~h})$, preincubated with either DMSO $(0.1 \%)$ or tautomycetin (TMT, $10 \mathrm{~nm}$ in DMSO). D, Group data of average mIPSC amplitudes, showing that preincubation with tautomycetin blocks the TNF $\alpha$-induced mIPSC amplitude reduction ( $n=10-13$ cells in each condition; two-way ANOVA, Bonferroni's post hoc test, ${ }^{* *} p<$

specific inhibitor tautomycetin (Fig. $8 C$ ). Consistent with results from culture recordings (Fig. 6), TNF $\alpha$ treatment caused a significant decrease in mIPSC amplitude that was blocked by pretreatment with tautomycetin (DMSO alone, $51.8 \pm 3.2 \mathrm{pA}$; $\mathrm{DMSO}+\mathrm{TNF} \alpha, 39.8 \pm 2.7 \mathrm{pA}$; tautomycetin alone, $48.4 \pm 2.0$ $\mathrm{pA}$; tautomycetin $+\mathrm{TNF} \alpha, 47.1 \pm 2.5 \mathrm{pA}$; Fig. $8 C, D)$. However, we did not observe any differences in MIPSC frequency (DMSO alone, $10.6 \pm 0.9 \mathrm{~Hz}$; DMSO + TNF $\alpha, 10.8 \pm 1.4 \mathrm{~Hz}$; tautomycetin alone, $8.1 \pm 0.7 \mathrm{~Hz}$; tautomycetin $+\mathrm{TNF} \alpha$, $8.5 \pm 0.7 \mathrm{~Hz}$; $n=10-13$ cells; two-way ANOVA, Bonferroni's post hoc test, $p>$ 0.05), suggesting that the effect observed in culture (Fig. 1) is 


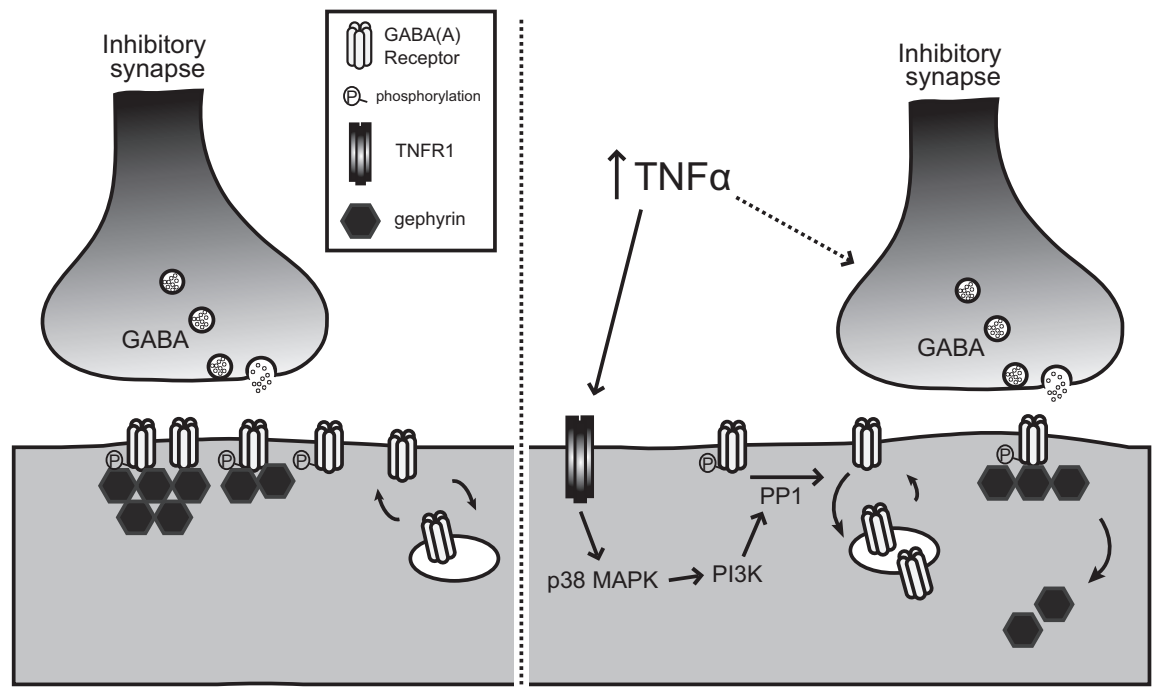

Figure 9. Proposed model for TNF $\alpha$-induced downregulation of GABAergic neurotransmission at hippocampal synapses. Compared with normal conditions (left), conditions associated with elevated levels of TNF $\alpha$ (right) lead to diminished postsynaptic responses to GABA as a result of lower levels of synaptic GABA $A_{A}$ Rs. Activation of TNFR1 signals through p38 MAPK, PI3K, and PP1, which in turn dephosphorylates $\beta 35408 / 409$ to enhance $G A B A_{A} R$ endocytosis. A reduction in synaptic $G A B A_{A} R s$ is followed by a reduction in gephyrin clustering. TNF $\alpha$ may also affect presynaptic function by reducing synaptic vesicle release probability at some synapses, without affecting GABA synthesis.

either culture specific or does not occur at GABAergic synapses onto CA1 pyramidal neurons.

\section{Discussion}

In this study, we characterized the effects of TNF $\alpha$ at GABAergic hippocampal synapses, defining the signaling pathway through which it controls $\mathrm{GABA}_{\mathrm{A}} \mathrm{R}$ endocytosis. We demonstrated that TNF $\alpha$ rapidly downregulates GABAergic synaptic strength and surface $\mathrm{GABA}_{\mathrm{A}}$ Rs via neuronal TNFR1 activation, p38 MAPK, $\mathrm{PI} 3 \mathrm{~K}, \mathrm{PP} 1$, and dynamin GTPase activity. This is accompanied by an enhanced association of PP $1 \alpha$ with $\mathrm{GABA}_{\mathrm{A}} \mathrm{R} \beta 3$ and dephosphorylation of $\beta 3 \mathrm{~S} 408 / 409$. Furthermore, on a longer timescale, gephyrin cluster density is also reduced. Together, these findings support a model whereby $\mathrm{TNF} \alpha$ rapidly and persistently tunes down inhibition by enhancing $\mathrm{GABA}_{\mathrm{A}} \mathrm{R}$ endocytosis through PP1-dependent dephosphorylation of $\beta 3$ subunits, which is then compounded by a loss of synaptic scaffolding support for GABA $_{\mathrm{A}}$ Rs (Fig. 9).

A large number of functionally distinct $\mathrm{GABA}_{\mathrm{A}} \mathrm{R}$ subtypes are assembled from various subunit combinations (Olsen and Sieghart, 2009). Our results indicate that receptors containing subunits $\alpha 1, \alpha 2, \beta 2 / 3$, and $\gamma 2$ - which are preferentially localized to synapses (Mangan et al., 2005; Michels and Moss, 2007)—are all reduced by $25-30 \%$ on the cell surface. Therefore, despite the differential subcellular distribution of $\alpha 1$ - and $\alpha 2$-containing receptors in vivo (Prenosil et al., 2006; Thomson and Jovanovic, 2010; Panzanelli et al., 2011), TNF $\alpha$ has similar effects on both receptor subtypes. In agreement with this, we observed no significant difference in mIPSC decay kinetics, which would be expected to change with an altered ratio of $\alpha 1$ - to $\alpha 2$-containing receptors remaining at the synapse (Okada et al., 2000; Bosman et al., 2005; Schneider Gasser et al., 2007). Furthermore, we observed a full shift in the cumulative distribution of mIPSC amplitudes, suggesting that all synapses were affected to a similar extent. Such a broad effect on synaptic receptor subtypes is probably achieved by controlling endocytosis through common components, such as the $\beta$ subunits. However, because we observed that surface levels of clustered $\alpha 5$-containing receptors-which also coassemble with $\beta$ subunits (Glykys and Mody, 2007) —are only modestly decreased, it is possible that some level of specificity is achieved at the subcellular level by differential activation of signaling molecules present at synaptic versus extrasynaptic compartments. Furthermore, some cell-type specificity of the effect is also likely because TNF $\alpha$ did not reduce surface levels of $\alpha 1$ subunits in a subpopulation of cells expressing high levels of $\alpha 1$. Although we are not certain what neuron subtype(s) this population represents, it probably consists of a mixture of hippocampal interneurons and a small fraction of subicular neurons introduced during the dissection procedure; both of these neuron types are known to express higher levels of the $\alpha 1$ subunit (Brünig et al., 2002; Yu et al., 2006; Schneider Gasser et al., 2007). It is possible that such neuron subtypes do not express some necessary component of the signaling pathway linking TNF $\alpha$ to $\mathrm{GABA}_{\mathrm{A}} \mathrm{R}$ trafficking.

In addition to $\mathrm{GABA}_{\mathrm{A}} \mathrm{R}$ content at the synapse, TNF $\alpha$ also regulated clustering of gephyrin, a scaffolding protein that helps maintain a high density of $\mathrm{GABA}_{\mathrm{A}} \mathrm{Rs}$ at the inhibitory synapse by directly interacting with $\mathrm{GABA}_{\mathrm{A}} \mathrm{R}$ subunits (Tretter et al., 2012; Kowalczyk et al., 2013). We determined that, whereas surface $\gamma 2$ clusters were rapidly reduced within $45 \mathrm{~min}$, gephyrin clustering was reduced more slowly, reaching a minimum after $3 \mathrm{~h}$. Because loss of gephyrin is known to disrupt $\mathrm{GABA}_{\mathrm{A}} \mathrm{R}$ clustering by increasing receptor lateral mobility (Jacob et al., 2005; Yu et al., 2007), the $\mathrm{TNF} \alpha$-induced slow reduction in gephyrin clustering is likely to destabilize synaptic $\mathrm{GABA}_{\mathrm{A}} \mathrm{R}$ clusters, thus serving as a second mechanism via which $\mathrm{TNF} \alpha$ weakens inhibitory synapses. We suspect that the decrease in gephyrin clustering occurs in response to the initial reduction in surface levels of $\mathrm{GABA}_{\mathrm{A}} \mathrm{Rs}$. This would be consistent with reports documenting a loss of gephyrin clusters in $\alpha 1-\alpha 3$ and $\gamma 2$ knock-out mice (Essrich et al., 1998; Schweizer et al., 2003; Studer et al., 2006; Patrizi et al., 2008; Panzanelli et al., 2011). However, we cannot exclude the possibility that a separate $\mathrm{TNF} \alpha$ signaling pathway directly regulates gephyrin cluster density, perhaps by regulating phosphorylation of gephyrin (Tyagarajan et al., 2011).

TNF $\alpha$ is known to traffic AMPARs to the surface via neuronal TNFR1 (Stellwagen et al., 2005), whereas astrocytic TNFR1 can control the release of glutamate from astrocytes (Domercq et al., 2006). We now show that activation of neuronally expressed TNFR1 is necessary for the effects of TNF $\alpha$ on $G_{A B A} R$ trafficking, whereas astrocytic TNFR1 does not play a role in this pathway. Therefore, it is apparent that TNF $\alpha$ controls neurotransmitter receptor trafficking by acting directly on neurons rather than by acting on glial TNFR1 to induce the release of a glial factor that would subsequently signal to neurons. Furthermore, the divergence in signaling pathways controlling AMPARs exocytosis versus $\mathrm{GABA}_{\mathrm{A}} \mathrm{R}$ endocytosis must occur downstream of neuronal TNFR1. We provide evidence that p38 MAPK and PI3K are sequentially activated by TNF $\alpha$ and are required for TNF $\alpha$-dependent $\mathrm{GABA}_{\mathrm{A}} \mathrm{R}$ endocytosis. Through activation of $\mathrm{Akt}, \mathrm{PI} 3 \mathrm{~K}$ is known to regulate insulin-dependent translocation 
of $\mathrm{GABA}_{\mathrm{A}} \mathrm{Rs}$ to the neuronal cell surface (Wang et al., 2003). However, PI3K can also control PP1 activity (Ragolia and Begum, 1998; De Luca et al., 1999), suggesting that it can indirectly lead to receptor dephosphorylation.

Using several experimental approaches, we identified PP1 as a mediator of TNF $\alpha$-dependent $\mathrm{GABA}_{\mathrm{A}} \mathrm{R}$ trafficking in cultured hippocampal neurons and acute hippocampal slice CA1 pyramidal neurons. In addition, we have shown that, in response to $\mathrm{TNF} \alpha$ treatment, $\mathrm{GABA}_{\mathrm{A}} \mathrm{R} \beta 3$ is dephosphorylated at $\mathrm{S} 408 / 409$ via a signaling pathway that requires activation of $\mathrm{p} 38$ MAPK, PI3K, and PP1 but not PP2A. These data support a model of regulated endocytosis occurring via PP1-dependent dephosphorylation of $\beta 3$ subunits, which enhances the proportion of $\beta 3$ subunits bound to AP2 and consequently enhances dynamindependent endocytosis of $\mathrm{GABA}_{\mathrm{A}}$ Rs. Therefore, TNF $\alpha$ appears to engage a mechanism shown previously to mediate constitutive endocytosis of $\mathrm{GABA}_{\mathrm{A}} \mathrm{Rs}$ through phospho-dependent regulation of the $\beta 3-\mathrm{AP} 2$ interaction (Kittler et al., 2005; Smith et al., 2012). A similar mechanism of constitutive endocytosis has been described based on phosphorylation of the $\gamma 2$ subunit at Y365/ 367 (Kittler et al., 2008). Although we do not rule out TNF $\alpha$ dependent regulation of $\gamma 2$ phosphorylation, we suspect that this does not play a major role because we can completely block the effects of TNF $\alpha$ via serine/threonine phosphatase inhibition with okadaic acid, whereas phosphorylation of Y365/367 is regulated by tyrosine phosphatases (Brandon et al., 2001). Similarly, although phosphorylation of $\mathrm{GABA}_{\mathrm{A}}$ Rs can also affect channel gating (Brandon et al., 2002) and therefore could account for the decrease in MIPSC amplitude, we suspect this does not play a major role because the majority of the effect requires dynamin GTPase activity.

In culture experiments, we observed a decrease in MIPSC frequency in response to TNF $\alpha$ treatment, yet immunostaining for GAD65 revealed no effect on puncta density or size, suggesting no change in the number of GABA release sites or in GABA synthesis. We conclude that the decrease in event frequency is likely to be regulated by a decrease in release probability and perhaps to some extent by low-amplitude events falling below the detection threshold at higher concentrations of TNF $\alpha(>50 \mathrm{ng} / \mathrm{ml})$. Although we did not observe an effect of TNF $\alpha$ treatment on the frequency of mIPSCs recorded from CA1 pyramidal neurons in acute slices, it is possible that the effect is nonetheless present at inhibitory synapses onto other hippocampal neuron subtypes. For example, TNF $\alpha$ controls astrocyte-mediated presynaptic modulation at excitatory synapses onto dentate gyrus neurons (Santello et al., 2011).

TNF $\alpha$ is an important mediator of homeostatic synaptic plasticity and is upregulated during prolonged periods of neuronal inactivity, when it is required for the inverse regulation of AMPAR and $\mathrm{GABA}_{\mathrm{A}} \mathrm{R}$ trafficking (Stellwagen and Malenka, 2006). Our findings imply that such homeostatic downregulation of synaptic $\mathrm{GABA}_{\mathrm{A}} \mathrm{R}$ content is mechanistically distinct from the heterosynaptic depression of inhibitory synapses (inhibitory long-term depression; Castillo et al., 2011), which requires either calcineurin (Lu et al., 2000) or PP2A (Lu et al., 2010) rather than PP1 to dephosphorylate the receptor.

$\mathrm{TNF} \alpha$ is strongly upregulated in a number of neurological disorders, including epilepsy, autism spectrum disorder (ASD), and neurodegenerative diseases (Vezzani and Granata, 2005; Collins et al., 2012; Montgomery and Bowers, 2012; Onore et al., 2012). Mice lacking TNFR1 display reduced seizure susceptibility in the hippocampus, suggesting that TNFR1-dependent signaling enhances excitability in pathological states (Balosso et al.,
2005). Similarly, impairment in $\mathrm{GABA}_{\mathrm{A}} \mathrm{R}$ function achieved by knocking out the $\beta 3$ subunit produces electroencephalographic abnormalities and seizures (DeLorey et al., 1998; Liljelund et al., 2005), and epilepsy is associated with a downregulation of gephyrin and GABA $A_{A}$ Rs (González et al., 2013). Deficits in GABAergic neurotransmission are also implicated in ASD (Chao et al., 2010; Han et al., 2012), which is often accompanied by immune dysregulation and elevated levels of TNF $\alpha$ (Chez et al., 2007; Malik et al., 2011). It has been proposed that an elevation of the excitatory/ inhibitory ratio, which is regulated by TNF $\alpha$ (Stellwagen et al., 2005), is a major cause of ASD (Rubenstein and Merzenich, 2003; Yizhar et al., 2011). In summary, we propose that our findings provide a mechanistic link between the inflammatory component of certain neurological diseases and phenotypes associated with deficits in GABAergic neurotransmission.

\section{References}

Arancibia-Cárcamo IL, Kittler JT (2009) Regulation of GABA(A) receptor membrane trafficking and synaptic localization. Pharmacol Ther 123:17-31. CrossRef Medline

Balosso S, Ravizza T, Perego C, Peschon J, Campbell IL, De Simoni MG, Vezzani A (2005) Tumor necrosis factor-alpha inhibits seizures in mice via p75 receptors. Ann Neurol 57:804-812. CrossRef Medline

Bannai H, Lévi S, Schweizer C, Inoue T, Launey T, Racine V, Sibarita JB, Mikoshiba K, Triller A (2009) Activity-dependent tuning of inhibitory neurotransmission based on GABAAR diffusion dynamics. Neuron 62: 670-682. CrossRef Medline

Bausen M, Weltzien F, Betz H, O'Sullivan GA (2010) Regulation of postsynaptic gephyrin cluster size by protein phosphatase 1 . Mol Cell Neurosci 44:201-209. CrossRef Medline

Beattie EC, Stellwagen D, Morishita W, Bresnahan JC, Ha BK, Von Zastrow M, Beattie MS, Malenka RC (2002) Control of synaptic strength by glial TNFalpha. Science 295:2282-2285. CrossRef Medline

Bosman LW, Heinen K, Spijker S, Brussaard AB (2005) Mice lacking the major adult GABAA receptor subtype have normal number of synapses, but retain juvenile IPSC kinetics until adulthood. J Neurophysiol 94:338346. CrossRef Medline

Brambilla R, Ashbaugh JJ, Magliozzi R, Dellarole A, Karmally S, Szymkowski DE, Bethea JR (2011) Inhibition of soluble tumour necrosis factor is therapeutic in experimental autoimmune encephalomyelitis and promotes axon preservation and remyelination. Brain 134:2736-2754. CrossRef Medline

Brandon NJ, Delmas P, Kittler JT, McDonald BJ, Sieghart W, Brown DA, Smart TG, Moss SJ (2000) GABAA receptor phosphorylation and functional modulation in cortical neurons by a protein kinase C-dependent pathway. J Biol Chem 275:38856-38862. CrossRef Medline

Brandon NJ, Delmas P, Hill J, Smart TG, Moss SJ (2001) Constitutive tyrosine phosphorylation of the GABA(A) receptor gamma 2 subunit in rat brain. Neuropharmacology 41:745-752. CrossRef Medline

Brandon NJ, Jovanovic JN, Moss SJ (2002) Multiple roles of protein kinases in the modulation of gamma-aminobutyric $\operatorname{acid}(\mathrm{A})$ receptor function and cell surface expression. Pharmacol Ther 94:113-122. CrossRef Medline

Brandon NJ, Jovanovic JN, Colledge M, Kittler JT, Brandon JM, Scott JD, Moss SJ (2003) A-kinase anchoring protein 79/150 facilitates the phosphorylation of $\mathrm{GABA}(\mathrm{A})$ receptors by cAMP-dependent protein kinase via selective interaction with receptor beta subunits. Mol Cell Neurosci 22:87-97. CrossRef Medline

Brünig I, Scotti E, Sidler C, Fritschy JM (2002) Intact sorting, targeting, and clustering of gamma-aminobutyric acid A receptor subtypes in hippocampal neurons in vitro. J Comp Neurol 443:43-55. CrossRef Medline

Buddhala C, Hsu CC, Wu JY (2009) A novel mechanism for GABA synthesis and packaging into synaptic vesicles. Neurochem Int 55:9-12. CrossRef Medline

Caraiscos VB, Elliott EM, You-Ten KE, Cheng VY, Belelli D, Newell JG, Jackson MF, Lambert JJ, Rosahl TW, Wafford KA, MacDonald JF, Orser BA (2004) Tonic inhibition in mouse hippocampal CAl pyramidal neurons is mediated by alpha5 subunit-containing gamma-aminobutyric acid type A receptors. Proc Natl Acad Sci U S A 101:3662-3667. CrossRef Medline 
Castillo PE, Chiu CQ, Carroll RC (2011) Long-term plasticity at inhibitory synapses. Curr Opin Neurobiol 21:328-338. CrossRef Medline

Chao HT, Chen H, Samaco RC, Xue M, Chahrour M, Yoo J, Neul JL, Gong S, Lu HC, Heintz N, Ekker M, Rubenstein JL, Noebels JL, Rosenmund C, Zoghbi HY (2010) Dysfunction in GABA signalling mediates autismlike stereotypies and Rett syndrome phenotypes. Nature 468:263-269. CrossRef Medline

Chez MG, Dowling T, Patel PB, Khanna P, Kominsky M (2007) Elevation of tumor necrosis factor-alpha in cerebrospinal fluid of autistic children. Pediatr Neurol 36:361-365. CrossRef Medline

Cohen P, Klumpp S, Schelling DL (1989) An improved procedure for identifying and quantitating protein phosphatases in mammalian tissues. FEBS Lett 250:596-600. CrossRef Medline

Collins LM, Toulouse A, Connor TJ, Nolan YM (2012) Contributions of central and systemic inflammation to the pathophysiology of Parkinson's disease. Neuropharmacology 62:2154-2168. CrossRef Medline

Crestani F, Lorez M, Baer K, Essrich C, Benke D, Laurent JP, Belzung C, Fritschy JM, Lüscher B, Mohler H (1999) Decreased GABAA-receptor clustering results in enhanced anxiety and a bias for threat cues. Nat Neurosci 2:833-839. CrossRef Medline

DeLorey TM, Handforth A, Anagnostaras SG, Homanics GE, Minassian BA, Asatourian A, Fanselow MS, Delgado-Escueta A, Ellison GD, Olsen RW (1998) Mice lacking the beta3 subunit of the GABAA receptor have the epilepsy phenotype and many of the behavioral characteristics of Angelman syndrome. J Neurosci 18:8505-8514. Medline

De Luca JP, Garnache AK, Rulfs J, Miller TB Jr (1999) Wortmannin inhibits insulin-stimulated activation of protein phosphatase 1 in rat cardiomyocytes. Am J Physiol 276:H1520-H1526. Medline

Domercq M, Brambilla L, Pilati E, Marchaland J, Volterra A, Bezzi P (2006) P2Y1 receptor-evoked glutamate exocytosis from astrocytes: control by tumor necrosis factor-alpha and prostaglandins. J Biol Chem 281:3068430696. CrossRef Medline

Dopp JM, Mackenzie-Graham A, Otero GC, Merrill JE (1997) Differential expression, cytokine modulation, and specific functions of type- 1 and type-2 tumor necrosis factor receptors in rat glia. J Neuroimmunol 75: 104-112. CrossRef Medline

Duveau V, Laustela S, Barth L, Gianolini F, Vogt KE, Keist R, Chandra D, Homanics GE, Rudolph U, Fritschy JM (2011) Spatiotemporal specificity of GABAA receptor-mediated regulation of adult hippocampal neurogenesis. Eur J Neurosci 34:362-373. CrossRef Medline

Essrich C, Lorez M, Benson JA, Fritschy JM, Lüscher B (1998) Postsynaptic clustering of major GABAA receptor subtypes requires the gamma 2 subunit and gephyrin. Nat Neurosci 1:563-571. CrossRef Medline

Farrant M, Nusser Z (2005) Variations on an inhibitory theme: phasic and tonic activation of GABA(A) receptors. Nat Rev Neurosci 6:215-229. CrossRef Medline

Frankola KA, Greig NH, Luo W, Tweedie D (2011) Targeting TNF-alpha to elucidate and ameliorate neuroinflammation in neurodegenerative diseases. CNS Neurol Disord Drug Targets 10:391-403. CrossRef Medline

Fritschy JM, Paysan J, Enna A, Mohler H (1994) Switch in the expression of rat GABAA-receptor subtypes during postnatal development: an immunohistochemical study. J Neurosci 14:5302-5324. Medline

Fritschy JM, Panzanelli P, Tyagarajan SK (2012) Molecular and functional heterogeneity of GABAergic synapses. Cell Mol Life Sci 69:2485-2499. CrossRef Medline

Glykys J, Mody I (2007) Activation of GABAA receptors: views from outside the synaptic cleft. Neuron 56:763-770. CrossRef Medline

González MI, Cruz Del Angel Y, Brooks-Kayal A (2013) Down-regulation of gephyrin and $\mathrm{GABA}(\mathrm{A})$ receptor subunits during epileptogenesis in the CA1 region of hippocampus. Epilepsia 54:616-624. CrossRef Medline

Grivennikov SI, Kuprash DV, Liu ZG, Nedospasov SA (2006) Intracellular signals and events activated by cytokines of the tumor necrosis factor superfamily: From simple paradigms to complex mechanisms. Int Rev Cytol 252:129-161. CrossRef Medline

Han S, Tai C, Westenbroek RE, Yu FH, Cheah CS, Potter GB, Rubenstein JL, Scheuer T, de la Iglesia HO, Catterall WA (2012) Autistic-like behaviour in Scn 1a + / - mice and rescue by enhanced GABA-mediated neurotransmission. Nature 489:385-390. CrossRef Medline

He P, Liu Q, Wu J, Shen Y (2012) Genetic deletion of TNF receptor suppresses excitatory synaptic transmission via reducing AMPA receptor synaptic localization in cortical neurons. FASEB J 26:334-345. CrossRef Medline
Higuchi M, Aggarwal BB (1994) TNF induces internalization of the p60 receptor and shedding of the p80 receptor. J Immunol 152:3550-3558. Medline

Jacob TC, Bogdanov YD, Magnus C, Saliba RS, Kittler JT, Haydon PG, Moss SJ (2005) Gephyrin regulates the cell surface dynamics of synaptic GABAA receptors. J Neurosci 25:10469-10478. CrossRef Medline

Jacob TC, Moss SJ, Jurd R (2008) GABA(A) receptor trafficking and its role in the dynamic modulation of neuronal inhibition. Nat Rev Neurosci 9:331-343. CrossRef Medline

Jovanovic JN, Thomas P, Kittler JT, Smart TG, Moss SJ (2004) Brainderived neurotrophic factor modulates fast synaptic inhibition by regulating GABA(A) receptor phosphorylation, activity, and cell-surface stability. J Neurosci 24:522-530. CrossRef Medline

Kaech S, Banker G (2006) Culturing hippocampal neurons. Nat Protoc 1:2406-2415. CrossRef Medline

Kaneko M, Stellwagen D, Malenka RC, Stryker MP (2008) Tumor necrosis factor-alpha mediates one component of competitive, experiencedependent plasticity in developing visual cortex. Neuron 58:673-680. CrossRef Medline

Kanematsu T, Yasunaga A, Mizoguchi Y, Kuratani A, Kittler JT, Jovanovic JN, Takenaka K, Nakayama KI, Fukami K, Takenawa T, Moss SJ, Nabekura J, Hirata M (2006) Modulation of GABA(A) receptor phosphorylation and membrane trafficking by phospholipase C-related inactive protein/ protein phosphatase 1 and $2 \mathrm{~A}$ signaling complex underlying brainderived neurotrophic factor-dependent regulation of GABAergic inhibition. J Biol Chem 281:22180-22189. CrossRef Medline

Kanematsu T, Fujii M, Mizokami A, Kittler JT, Nabekura J, Moss SJ, Hirata M (2007) Phospholipase C-related inactive protein is implicated in the constitutive internalization of GABAA receptors mediated by clathrin and AP2 adaptor complex. J Neurochem 101:898-905. CrossRef Medline

Kasugai Y, Swinny JD, Roberts JD, Dalezios Y, Fukazawa Y, Sieghart W, Shigemoto R, Somogyi P (2010) Quantitative localisation of synaptic and extrasynaptic GABAA receptor subunits on hippocampal pyramidal cells by freeze-fracture replica immunolabelling. Eur J Neurosci 32:1868 1888. CrossRef Medline

Kittler JT, Delmas P, Jovanovic JN, Brown DA, Smart TG, Moss SJ (2000) Constitutive endocytosis of GABAA receptors by an association with the adaptin AP2 complex modulates inhibitory synaptic currents in hippocampal neurons. J Neurosci 20:7972-7977. Medline

Kittler JT, Chen G, Honing S, Bogdanov Y, McAinsh K, Arancibia-Carcamo IL, Jovanovic JN, Pangalos MN, Haucke V, Yan Z, Moss SJ (2005) Phospho-dependent binding of the clathrin AP2 adaptor complex to GABAA receptors regulates the efficacy of inhibitory synaptic transmission. Proc Natl Acad Sci U S A 102:14871-14876. CrossRef Medline

Kittler JT, Chen G, Kukhtina V, Vahedi-Faridi A, Gu Z, Tretter V, Smith KR, McAinsh K, Arancibia-Carcamo IL, Saenger W, Haucke V, Yan Z, Moss SJ (2008) Regulation of synaptic inhibition by phospho-dependent binding of the AP2 complex to a YECL motif in the GABAA receptor gamma2 subunit. Proc Natl Acad Sci U S A 105:3616-3621. CrossRef Medline

Kneussel M, Brandstätter JH, Laube B, Stahl S, Müller U, Betz H (1999) Loss of postsynaptic $\mathrm{GABA}_{\mathrm{A}}$ receptor clustering in gephyrin-deficient mice. J Neurosci 19:9289-9297. Medline

Kowalczyk S, Winkelmann A, Smolinsky B, Förstera B, Neundorf I, Schwarz G, Meier JC (2013) Direct binding of GABA(A) receptor beta2 and beta3 subunits to gephyrin. Eur J Neurosci 37:544-554. CrossRef Medline

Lau CG, Murthy VN (2012) Activity-dependent regulation of inhibition via GAD67. J Neurosci 32:8521-8531. CrossRef Medline

Leonoudakis D, Zhao P, Beattie EC (2008) Rapid tumor necrosis factor alpha-induced exocytosis of glutamate receptor 2-lacking AMPA receptors to extrasynaptic plasma membrane potentiates excitotoxicity. J Neurosci 28:2119-2130. CrossRef Medline

Lévi S, Logan SM, Tovar KR, Craig AM (2004) Gephyrin is critical for glycine receptor clustering but not for the formation of functional GABAergic synapses in hippocampal neurons. J Neurosci 24:207-217. CrossRef Medline

Liljelund P, Handforth A, Homanics GE, Olsen RW (2005) GABAA receptor beta3 subunit gene-deficient heterozygous mice show parent-oforigin and gender-related differences in beta3 subunit levels, EEG, and behavior. Brain Res Dev Brain Res 157:150-161. CrossRef Medline

Lin HC, Tseng YC, Mao SC, Chen PS, Gean PW (2011) GABAA receptor endocytosis in the basolateral amygdala is critical to the reinstatement of 
fear memory measured by fear-potentiated startle. J Neurosci 31:88518861. CrossRef Medline

Lu H, Cheng PL, Lim BK, Khoshnevisrad N, Poo MM (2010) Elevated BDNF after cocaine withdrawal facilitates LTP in medial prefrontal cortex by suppressing GABA inhibition. Neuron 67:821-833. CrossRef Medline

Lu YM, Mansuy IM, Kandel ER, Roder J (2000) Calcineurin-mediated LTD of GABAergic inhibition underlies the increased excitability of CA1 neurons associated with LTP. Neuron 26:197-205. CrossRef Medline

Luscher B, Fuchs T, Kilpatrick CL (2011) GABAA receptor traffickingmediated plasticity of inhibitory synapses. Neuron 70:385-409. CrossRef Medline

MacEwan DJ (2002) TNF receptor subtype signalling: differences and cellular consequences. Cell Signal 14:477-492. CrossRef Medline

Macia E, Ehrlich M, Massol R, Boucrot E, Brunner C, Kirchhausen T (2006) Dynasore, a cell-permeable inhibitor of dynamin. Dev Cell 10:839-850. CrossRef Medline

Malik M, Sheikh AM, Wen G, Spivack W, Brown WT, Li X (2011) Expression of inflammatory cytokines, $\mathrm{Bcl} 2$ and cathepsin $\mathrm{D}$ are altered in lymphoblasts of autistic subjects. Immunobiology 216:80-85. CrossRef Medline

Mangan PS, Sun C, Carpenter M, Goodkin HP, Sieghart W, Kapur J (2005) Cultured hippocampal pyramidal neurons express two kinds of GABAA receptors. Mol Pharmacol 67:775-788. CrossRef Medline

Mann EO, Paulsen O (2007) Role of GABAergic inhibition in hippocampal network oscillations. Trends Neurosci 30:343-349. CrossRef Medline

McCoy MK, Tansey MG (2008) TNF signaling inhibition in the CNS: implications for normal brain function and neurodegenerative disease. J Neuroinflammation 5:45. CrossRef Medline

McDonald BJ, Amato A, Connolly CN, Benke D, Moss SJ, Smart TG (1998) Adjacent phosphorylation sites on GABAA receptor beta subunits determine regulation by cAMP-dependent protein kinase. Nat Neurosci 1:23-28. CrossRef Medline

Michels G, Moss SJ (2007) GABAA receptors: properties and trafficking. Crit Rev Biochem Mol Biol 42:3-14. CrossRef Medline

Mitsuhashi S, Matsuura N, Ubukata M, Oikawa H, Shima H, Kikuchi K (2001) Tautomycetin is a novel and specific inhibitor of serine/threonine protein phosphatase type 1, PP1. Biochem Biophys Res Commun 287: 328-331. CrossRef Medline

Möhler H, Fritschy JM, Crestani F, Hensch T, Rudolph U (2004) Specific GABA(A) circuits in brain development and therapy. Biochem Pharmacol 68:1685-1690. CrossRef Medline

Montgomery SL, Bowers WJ (2012) Tumor necrosis factor-alpha and the roles it plays in homeostatic and degenerative processes within the central nervous system. J Neuroimmune Pharmacol 7:42-59. CrossRef Medline

Mosselmans R, Hepburn A, Dumont JE, Fiers W, Galand P (1988) Endocytic pathway of recombinant murine tumor necrosis factor in L-929 cells. J Immunol 141:3096-3100. Medline

Muir J, Arancibia-Carcamo IL, MacAskill AF, Smith KR, Griffin LD, Kittler JT (2010) NMDA receptors regulate GABAA receptor lateral mobility and clustering at inhibitory synapses through serine 327 on the gamma2 subunit. Proc Natl Acad Sci U S A 107:16679-16684. CrossRef Medline

Mukherjee J, Kretschmannova K, Gouzer G, Maric HM, Ramsden S, Tretter V, Harvey K, Davies PA, Triller A, Schindelin H, Moss SJ (2011) The residence time of GABA(A)Rs at inhibitory synapses is determined by direct binding of the receptor alphal subunit to gephyrin. J Neurosci 31:14677-14687. CrossRef Medline

Ogoshi F, Yin HZ, Kuppumbatti Y, Song B, Amindari S, Weiss JH (2005) Tumor necrosis-factor-alpha (TNF-alpha) induces rapid insertion of Ca2+-permeable alpha-amino-3-hydroxyl-5-methyl-4-isoxazole-propionate (AMPA)/kainate $(\mathrm{Ca}-\mathrm{A} / \mathrm{K})$ channels in a subset of hippocampal pyramidal neurons. Exp Neurol 193:384-393. CrossRef Medline

Okada M, Onodera K, Van Renterghem C, Sieghart W, Takahashi T (2000) Functional correlation of GABA(A) receptor alpha subunits expression with the properties of IPSCs in the developing thalamus. J Neurosci 20: 2202-2208. Medline

Olsen RW, Sieghart W (2009) GABA A receptors: subtypes provide diversity of function and pharmacology. Neuropharmacology 56:141-148. CrossRef Medline

Onore C, Careaga M, Ashwood P (2012) The role of immune dysfunction in the pathophysiology of autism. Brain Behav Immun 26:383-392. CrossRef Medline

Pallotto M, Nissant A, Fritschy JM, Rudolph U, Sassoè-Pognetto M, Pan- zanelli P, Lledo PM (2012) Early formation of GABAergic synapses governs the development of adult-born neurons in the olfactory bulb. J Neurosci 32:9103-9115. CrossRef Medline

Panzanelli P, Gunn BG, Schlatter MC, Benke D, Tyagarajan SK, Scheiffele P, Belelli D, Lambert JJ, Rudolph U, Fritschy JM (2011) Distinct mechanisms regulate GABAA receptor and gephyrin clustering at perisomatic and axo-axonic synapses on CA1 pyramidal cells. J Physiol 589:4959_ 4980. CrossRef Medline

Patrizi A, Scelfo B, Viltono L, Briatore F, Fukaya M, Watanabe M, Strata P, Varoqueaux F, Brose N, Fritschy JM, Sassoè-Pognetto M (2008) Synapse formation and clustering of neuroligin-2 in the absence of GABAA receptors. Proc Natl Acad Sci U S A 105:13151-13156. CrossRef Medline

Pirker S, Schwarzer C, Wieselthaler A, Sieghart W, Sperk G (2000) GABA(A) receptors: immunocytochemical distribution of 13 subunits in the adult rat brain. Neuroscience 101:815-850. CrossRef Medline

Prenosil GA, Schneider Gasser EM, Rudolph U, Keist R, Fritschy JM, Vogt KE (2006) Specific subtypes of GABAA receptors mediate phasic and tonic forms of inhibition in hippocampal pyramidal neurons. J Neurophysiol 96:846-857. CrossRef Medline

Ragolia L, Begum N (1998) Protein phosphatase-1 and insulin action. Mol Cell Biochem 182:49-58. CrossRef Medline

Rannals MD, Kapur J (2011) Homeostatic strengthening of inhibitory synapses is mediated by the accumulation of $\mathrm{GABA}_{\mathrm{A}}$ receptors. J Neurosci 31:17701-17712. CrossRef Medline

Rubenstein JL, Merzenich MM (2003) Model of autism: increased ratio of excitation/inhibition in key neural systems. Genes Brain Behav 2:255267. CrossRef Medline

Santello M, Bezzi P, Volterra A (2011) TNFalpha controls glutamatergic gliotransmission in the hippocampal dentate gyrus. Neuron 69:9881001. CrossRef Medline

Schneider Gasser EM, Duveau V, Prenosil GA, Fritschy JM (2007) Reorganization of GABAergic circuits maintains GABAA receptor-mediated transmission onto CA1 interneurons in alphal-subunit-null mice. Eur J Neurosci 25:3287-3304. CrossRef Medline

Schweizer C, Balsiger S, Bluethmann H, Mansuy IM, Fritschy JM, Mohler H, Lüscher B (2003) The gamma 2 subunit of GABA(A) receptors is required for maintenance of receptors at mature synapses. Mol Cell Neurosci 24:442-450. CrossRef Medline

Smith KR, Muir J, Rao Y, Browarski M, Gruenig MC, Sheehan DF, Haucke V, Kittler JT (2012) Stabilization of GABA $A_{\mathrm{A}}$ receptors at endocytic zones is mediated by an AP2 binding motif within the $\mathrm{GABA}_{\mathrm{A}}$ receptor $\beta 3$ subunit. J Neurosci 32:2485-2498. CrossRef Medline

Sriram K, O'Callaghan JP (2007) Divergent roles for tumor necrosis factoralpha in the brain. J Neuroimmune Pharmacol 2:140-153. CrossRef Medline

Steinmetz CC, Turrigiano GG (2010) Tumor necrosis factor-alpha signaling maintains the ability of cortical synapses to express synaptic scaling. J Neurosci 30:14685-14690. CrossRef Medline

Stellwagen D, Malenka RC (2006) Synaptic scaling mediated by glial TNFalpha. Nature 440:1054-1059. CrossRef Medline

Stellwagen D, Beattie EC, Seo JY, Malenka RC (2005) Differential regulation of AMPA receptor and GABA receptor trafficking by tumor necrosis factor- $\alpha$. J Neurosci 25:3219-3228. CrossRef Medline

Studer R, von Boehmer L, Haenggi T, Schweizer C, Benke D, Rudolph U, Fritschy JM (2006) Alteration of GABAergic synapses and gephyrin clusters in the thalamic reticular nucleus of $\mathrm{GABA}_{\mathrm{A}}$ receptor $\alpha 3$ subunitnull mice. Eur J Neurosci 24:1307-1315. CrossRef Medline

Suh YH, Park JY, Park S, Jou I, Roche PA, Roche KW (2013) Regulation of metabotropic glutamate receptor 7 (mGluR7) internalization and surface expression by Ser/Thr protein phosphatase 1. J Biol Chem 288:1754417551. CrossRef Medline

Surmeier DJ, Bargas J, Hemmings HC Jr, Nairn AC, Greengard P (1995) Modulation of calcium currents by a D1 dopaminergic protein kinase/ phosphatase cascade in rat neostriatal neurons. Neuron 14:385-397. CrossRef Medline

Tancredi V, D’Arcangelo G, Grassi F, Tarroni P, Palmieri G, Santoni A, Eusebi F (1992) Tumor necrosis factor alters synaptic transmission in rat hippocampal slices. Neurosci Lett 146:176-178. CrossRef Medline

Terunuma M, Jang IS, Ha SH, Kittler JT, Kanematsu T, Jovanovic JN, Nakayama KI, Akaike N, Ryu SH, Moss SJ, Hirata M (2004) GABAA receptor phospho-dependent modulation is regulated by phospholipase 
C-related inactive protein type 1 , a novel protein phosphatase 1 anchoring protein. J Neurosci 24:7074-7084. CrossRef Medline

Thomson AM, Jovanovic JN (2010) Mechanisms underlying synapsespecific clustering of GABA(A) receptors. Eur J Neurosci 31:2193-2203. CrossRef Medline

Tonelli LH, Postolache TT (2005) Tumor necrosis factor alpha, interleukin- 1 beta, interleukin- 6 and major histocompatibility complex molecules in the normal brain and after peripheral immune challenge. Neurol Res 27:679-684. CrossRef Medline

Tretter V, Jacob TC, Mukherjee J, Fritschy JM, Pangalos MN, Moss SJ (2008) The clustering of $\mathrm{GABA}_{\mathrm{A}}$ receptor subtypes at inhibitory synapses is facilitated via the direct binding of receptor alpha 2 subunits to gephyrin. J Neurosci 28:1356-1365. CrossRef Medline

Tretter V, Mukherjee J, Maric HM, Schindelin H, Sieghart W, Moss SJ (2012) Gephyrin, the enigmatic organizer at GABAergic synapses. Front Cell Neurosci 6:23. CrossRef Medline

Tyagarajan SK, Ghosh H, Yévenes GE, Nikonenko I, Ebeling C, Schwerdel C, Sidler C, Zeilhofer HU, Gerrits B, Muller D, Fritschy JM (2011) Regulation of GABAergic synapse formation and plasticity by GSK3betadependent phosphorylation of gephyrin. Proc Natl Acad Sci U S A 108: 379-384. CrossRef Medline

Vey E, Burger D, Dayer JM (1996) Expression and cleavage of tumor necrosis factor-alpha and tumor necrosis factor receptors by human monocytic cell lines upon direct contact with stimulated T cells. Eur J Immunol 26:2404-2409. CrossRef Medline

Vezzani A, Granata T (2005) Brain inflammation in epilepsy: experimental and clinical evidence. Epilepsia 46:1724-1743. CrossRef Medline

Walsh AH, Cheng A, Honkanen RE (1997) Fostriecin, an antitumor antibiotic with inhibitory activity against serine/threonine protein phosphatases types 1 (PP1) and 2A (PP2A), is highly selective for PP2A. FEBS Lett 416:230-234. CrossRef Medline

Wang Q, Liu L, Pei L, Ju W, Ahmadian G, Lu J, Wang Y, Liu F, Wang YT
(2003) Control of synaptic strength, a novel function of Akt. Neuron 38:915-928. CrossRef Medline

Yanagihori S, Terunuma M, Koyano K, Kanematsu T, Ho Ryu S, Hirata M (2006) Protein phosphatase regulation by PRIP, a PLC-related catalytically inactive protein-implications in the phospho-modulation of the GABAA receptor. Adv Enzyme Regul 46:203-222. CrossRef Medline

Yin HZ, Hsu CI, Yu S, Rao SD, Sorkin LS, Weiss JH (2012) TNF-alpha triggers rapid membrane insertion of $\mathrm{Ca}(2+)$ permeable AMPA receptors into adult motor neurons and enhances their susceptibility to slow excitotoxic injury. Exp Neurol 238:93-102. CrossRef Medline

Yirmiya R, Goshen I (2011) Immune modulation of learning, memory, neural plasticity and neurogenesis. Brain Behav Immun 25:181-213. CrossRef Medline

Yizhar O, Fenno LE, Prigge M, Schneider F, Davidson TJ, O'Shea DJ, Sohal VS, Goshen I, Finkelstein J, Paz JT, Stehfest K, Fudim R, Ramakrishnan C, Huguenard JR, Hegemann P, Deisseroth K (2011) Neocortical excitation/inhibition balance in information processing and social dysfunction. Nature 477:171-178. CrossRef Medline

Yu W, Jiang M, Miralles CP, Li RW, Chen G, de Blas AL (2007) Gephyrin clustering is required for the stability of GABAergic synapses. Mol Cell Neurosci 36:484-500. CrossRef Medline

Yu ZY, Wang W, Fritschy JM, Witte OW, Redecker C (2006) Changes in neocortical and hippocampal GABAA receptor subunit distribution during brain maturation and aging. Brain Res 1099:73-81. CrossRef Medline

Zhang DW, Shao J, Lin J, Zhang N, Lu BJ, Lin SC, Dong MQ, Han J (2009) RIP3, an energy metabolism regulator that switches TNF-induced cell death from apoptosis to necrosis. Science 325:332-336. CrossRef Medline

Zhang H, Nei H, Dougherty PM (2010) A p38 mitogen-activated protein kinase-dependent mechanism of disinhibition in spinal synaptic transmission induced by tumor necrosis factor- $\alpha$. J Neurosci 30:12844-12855 CrossRef Medline 